
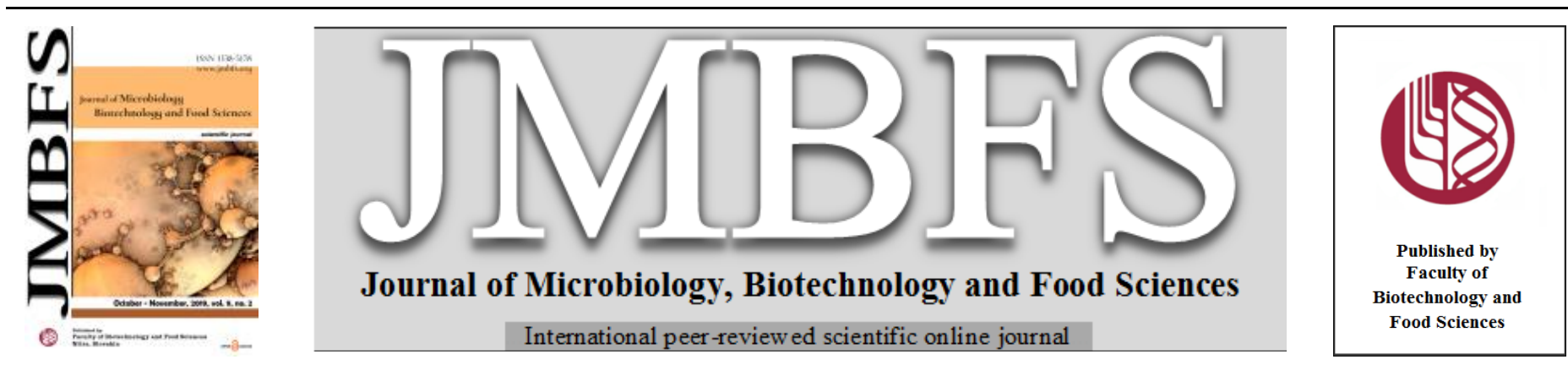

\title{
L-ASPARAGINASE AND L-GLUTAMINASE: SOURCES, PRODUCTION, AND APPLICATIONS IN MEDICINE AND INDUSTRY
}

\author{
Hanaa M.Orabi ${ }^{l}$,Esmail M. El-Fakharany*2, Eman S. Abdelkhalek ${ }^{l}$,Nagwa M. Sidkey ${ }^{l}$
}

\section{Address(es):}

${ }^{1}$ Botany and Microbiology Department, Faculty of Science, Al-Azhar University, Cairo,35527, Egypt.

${ }^{2}$ Protein Research Department, Medical Biotechnology Department, Genetic Engineering and Biotechnology Research Institute, City for Scientific Research and Technology Applications (SRTA-City), Alexandria,21934, Egypt.

*Corresponding author: esmailelfakharany@yahoo.co.uk

doi: 10.15414/jmbfs.2019.9.2.179-190

\section{ARTICLE INFO}

Received 8. 9. 2018

Revised 25. 3. 2019

Accepted 25. 3. 2019

Published 1. 10. 2019

$\overline{\text { Review }}$

\begin{abstract}
Amidases (L-asparaginase and L-glutaminase) catalyze the deamination process of L-asparagine and L-glutamine to their corresponding acidic form with ammonia releasing. Both enzymes are considered one of the most biomedical and biotechnologically important groups of enzymes, besides their international contributing as an important commercial products. L-asparaginase and L-glutaminase have been receiving more attention as antileukemic agent for treatment of acute lymphoblastic leukemia (ALL) and other types of cancer. On the other hand, these enzymes also used in food manufacture for their hydrolysis effect and is a possible way to decrease the amount of free L-asparagine in the preliminary ingredients of food making, thus minimize the imminent risk of causing neurotoxic and carcinogenic acrylamide compound which formed when food heated above $120{ }^{\circ} \mathrm{C}$. Glutamic and aspartic acid are important amino acids in food processing achieve a delicious, fine, sour and umami taste beside their nutritional important to food. A recent review discusses the mode of action of L-asparaginase and L-glutaminase. Also, this review lists the sources of L-asparaginase and L-glutaminase, production optimization of enzymes, and uses of the two enzymes in cancer therapy and other industrial purposes.
\end{abstract}

Keywords: L-asparaginase, L-glutaminase, Sources, Fermentation, Applications

\section{INTRODUCTION}

L-asparaginase and L-glutaminase are members of homologous amidohydrolase enzymes, which hydrolyze asparagine and glutamine into their acids and ammonia. Enzymes are very specific and selective catalytic proteins created by living cells to control, regulate and accelerate the biochemical process in the body (Sabu $\boldsymbol{e t}$ al., 2000). Microorganisms characterize as a major source of many therapeutic enzymes due to their susceptibility to genetic manipulation and their extensive biochemical variety. Nowadays microbial enzymes have an important role in the biochemical investigation, diagnosis, curing, and monitoring of many dreaded diseases. L-asparaginase and L-glutaminase (L-asparagine amidohydrolase E.C. 3.5.1.1; L-glutamine amidohydrolase EC 3.5.1.2) have been proved to be particularly promising enzymes in the treatment of acute lymphocytic leukemia (ALL) mainly in children (Vidhya et al. 2010; Unissa et al., 2014). L-asparaginase also has a therapeutic effect in the treatment of acute myelomonocytic leukemia, Hodgkin disease, acute myelocytic leukemia, melanosarcoma lymphosarcoma treatment, reticulosarbom and chronic lymphocytic leukemia (Wetzler et al., 2007) and L-glutaminase has an antiviral effect (Kumar and Chandrasekaran 2003). The first observation of the two enzymes as anticancer agent; asparaginase began in 1922 when Calimanti observed enzyme at high activity in serum of guinea pig. Kidd in 1953, when he applied serum of guinea pig for transplanted rat leukemia, suppression occurred. In the time between 1953 and 1972, many observations confirm these results. Yalin and Wriston in 1966 purified the two isoforms of L-asparaginase from the serum of genie pig and also from microorganisms. In the same side, the first observation for L-glutaminase as antileukaemia agent was in 1964 by Greenberg et al. Followed by El-Asmar and Greenberg in 1966 when they indicated that L-glutaminase from Pseudomonas sp. had an inhibition effect on rat carcinomas but it had little effect on the survival time of experimental animals. At $\mathbf{1 9 7 0}$ Roberts et al. proved that L-glutaminase from Gram-negative rod-shaped bacterium suppressed Ehrlich ascites carcinoma. L-asparaginase also used in food technology, to reduce the amount of free asparagine in the beginning materials due to its ability to hydrolysis of asparagine to aspartate and ammonia, so that the risk of making a potentially carcinogenic and neurotoxic acrylamide in food product decreased (Nanda et al., 2003). Glutaminase also used as flavor enhancing agent to the presence of glutamate (Wakayama et al., 2005). Lglutaminase and L-asparaginase used in food processing for their hydrolysis activities and the l-glutamine and L-asparagine produced considered importan amino acids in food manufacturing for a delicious and fine taste, Sour and Umami taste and nutritional important to the food products (Nanda et al., 2003). Sinha et al. (2013) reported L-asparaginases and L-glutaminases play a vital role in the biosynthesis of fine-chemicals. The researcher also used L-glutaminase as biosensors to monitoring L-glutamine level in mammalian and hybridoma cell lines (Huang et al., 2006). Two related families of asparaginase are designated type I and type II according to the terminology in Escherichia coli, which has both: L-asparaginase I is a low-affinity enzyme found in the cytoplasm, while Lasparaginase II is a high-affinity secreted enzyme synthesized with a cleavable signal sequence. Archaeal putative asparaginases are involved in type I but have an extra $\sim 80$ residues in a conserved $\mathrm{N}$-terminal region (Vidya and Vasudevan, 2011). On the other hand, L-glutaminases members tend to be designated as glutaminase A (glsA), where B (glsB) is unknown and may not be homologous (as in Rhizobium etli) some species have two isozymes that may both be designated A (GlsA1 and GlsA2) (Botman et al., 2014).

\section{BIOLOGICAL ROLE AND MODE OF ACTION OF L-ASPARAGINASE AND L-GLUTAMINASE}

Cancer treatment by enzyme therapy could be provided with either the use of enzyme prodrug therapy or the use of antineoplastic enzyme therapy. Enzyme prodrug therapy uses antibody-conjugated enzymes, converting prodrug into cytotoxic drug at tumor cells and thereby killing tumor cells. A technique using amino acid deprivation methodology for anti-cancer therapy where depletion, thereby the inductions of starvation of amino acids are attained in tumor cells which are auxotrophic to particular amino acids. This often reduces tumor proliferation. In both normal cells and tumor cells cannot synthesize L-asparagine and L-glutamine although they need them in large amount for cell growth. Asparagine and glutamine are non-essential amino acids used by immature lymphocytes for their proliferation and run as substrate for respiration, nitrogen for the production of hexosamines, proteins, and macromolecules (Unissa et al. 2014). Therefore, they are considered one of the key molecules in cancer 
metabolism through cell proliferation. In a healthy cell, asparagine and glutamine synthetases convert aspartate to asparagine and glutamate to glutamine, respectively by using ATP as a source of energy (Figures $1 \mathrm{a}$ or b and $2 \mathrm{a}$ or b). While in cancer cells, they need an extraordinarily high amount for the amino acid asparagine and glutamine and cannot synthesize adequate endogenous of these amino acids due to deficiency in levels of L-asparagine and L-glutamine synthetase and consequently are reliant on serum levels for their proliferation and survival (Miller et al., 1969) or the failure of these cells to increase L-asparagine and L-glutamine synthetase level (limited) (Gaffar and Shethna, 1977). Hence, administration of L-asparaginase and L-glutaminase eradicates reliant on the extracellular source of L-asparagine and L-glutamine and lead to apoptosis (Miki et al., 2005). Still, healthy cells unaffected by way of them are gifted by synthesizing asparagine and glutamine de novo with the aid of the enzymes Lasparagine and L-glutamine synthetase (Kumar and Sobha, 2012; Unissa et al. 2014).

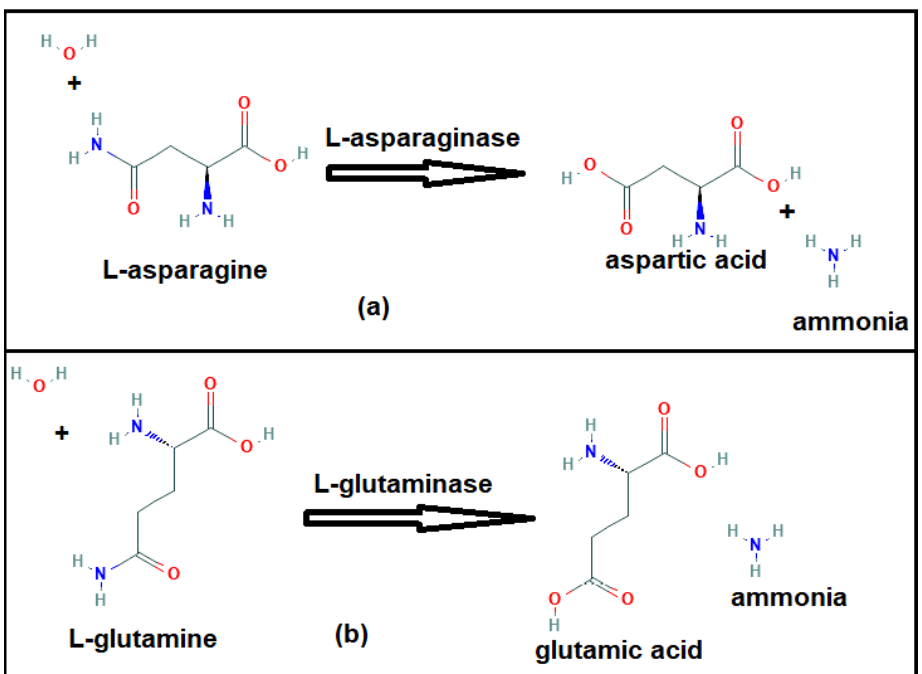

Figure 1 Schematic representation of the mode of action of a) L-asparaginase, b) L-glutaminase.

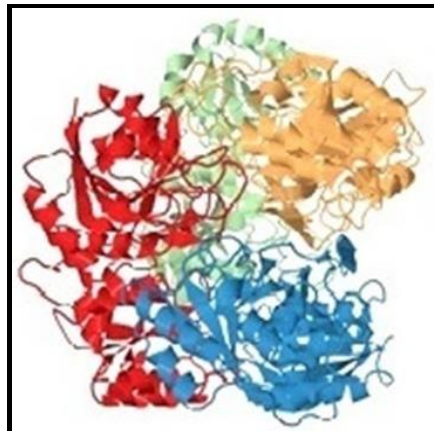

(a)

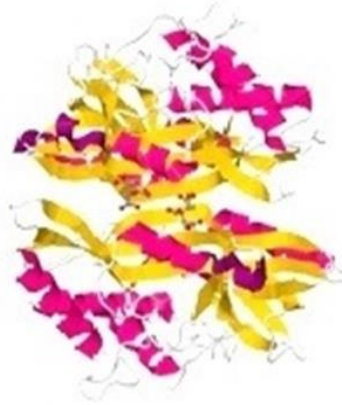

(b)
Figure 2 Crystal structure of a) L-asparaginase of Escherichia coli (PDB code 3ECA) (Swain et al., 1993), b) dimeric protein-glutaminase from Chryseobacterium proteolyticum (PDB: 3A56) (Hashizume et al., 2011).

\section{SOURCES OF L-ASPARAGINASE AND L-GLUTAMINASE}

\section{BACTERIAL SOURCES}

The most potent enzymes used for the treatment of leukemia for more than 40 years are bacterial sources which are mostly produced from Erwinia carotovora and E. coli (Huang et al., 2006). Most of Enterobacteriaceae family members produce only L-asparaginase, while Pseudomonas species produce both Lasparaginase and L-glutaminase (Imada et al., 1973, Dutta et al., 2015). Serratia marcescens SB08, E. coli, P. pseudoalcaligenes JHS-71, and E. carotovora produce L-asparaginase intracellularly (Venil $\boldsymbol{e t}$ al., 2009; Sajitha $\boldsymbol{e t}$ al., 2015; Badoei-Dalfard 2016; Faret et al., 2018), while $P$. aeruginosa 50071 and B. subtilis WB600 produce L-asparaginase extracellularly (ElBessoumy et al., 2004; Yue et al., 2017). In other hand, L-glutaminase produced extracellularly by Vibrio azureus JK-79, and P. otitidis (Kiruthika and Nachimuthu, 2013; Husain et al., 2016). Not all bacterial amidases have anticancer activities; the anticancer effect of these enzymes varies according to their affinity for substrates and their clearance rate (EI-Ghonemy, 2014).

\section{FUNGAL SOURCES}

Different fungal isolates from varies environments and origins show high Lasparaginase and L- glutaminase activities. Fusarium, aspergillus, and penicillium are the most reported and common fungi used for both enzymes production (Curran et al., 1985; Elshafei et al., 2014). L-asparaginase with antioxidant properties produced by Aspergillus sp. and Aspergillus oryzae (Soniyamby et al., 2011; Sudarkodi and Sunda, 2018). In case of Aspergillus sojae and Beauveria sp. have extracellular L-glutaminase activity and also Trichoderma koningii (Sabu et al., 2000; Pallem et al., 2010; Ito et al., 2013). While intracellular L-glutaminase free L-asparaginase is obtained from Penicillium brevicompactum NRC 829 (Elshafei et al., 2012).

The preproduction of L-asparaginase and L-glutaminase are also produced from yeast by Pichia polymorpha (Foda et al., 1980). Rhodotorula rosa and Cndida utils produce L-asparaginase extracellularly, whereas Saccharomyces cervisiae produce it intracellularly (Arima et al., 1972; Bon et al., 1997; Costa et al., 2016). Cryptococcus albidus, Hansenula jadini, Candida scottii, Zygosaccharomyces rouxii and Rhodotorula rubra have L-glutaminase activity (Kashyap et al., 2002, Iyer and Singhal, 2009; Unissa et al., 2014).

\section{ACTINOMYCETES}

Actinomycetes are widely distributed in terrestrial and marine habitats. They have commercial significance due to their capability to form novel metabolites Actinomycetes are considered as comparatively less explored source for Lasparaginase and L-glutaminase production and therefore act as candidates for the production of these enzymes. Actinomycetes like $S$. griseoluteus (Kumar et al., 2011), Nocardia levis and Streptomyces ginsengisoli (Deshpande et al., 2014) were reported to be potential producers of L-asparaginase. Sterptomyces sp. especially act as a source for L-asparaginase and L-glutaminase. S. griseus (Dejong, 1972), S. karnatakensis, S. venezuelae (Mostafa, 1979), Nocardia asteroids (Gunasekaran et al., 1995), S. albidoflavus (Narayana et al., 2008), $S$ gulbargensis (Amena et al., 2010) and S. parvus NEAE-95 (El-Naggar, 2015) all have L-asparaginase activity. In addtion, S. cyaneus, S. exfoliates and $S$. phaeochromogenes were found to be potential candidates for production of $\mathrm{L}$ asparaginase (Saxena et al., 2015). While few actinomycetes like S. rimosus, $S$. olivochromogenes, and $S$. pratensis NRC 10 have L-glutaminase activity (Balagurunathan et al., 2010; Tork et al., 2018). Abdallah et al. (2012) reported that both $S$. avermitilis and $S$. Labedae strains possess remarkable ability to produce L-glutaminase. Also, Abd-Alla et al. (2013) reported that $S$. variabilis that isolated from Rhizosphere of Triticum Vulgaris has the capicity to produce L-.glutaminase.

\section{PLANTS}

Several plants such as tamarind, chillies and tomato contain appreciable quantities of L-asparaginase and L-glutaminase; onions, potatoes and lemons have trace quantities, whereas both enzymes could not be identified in ginger and drumsticks (Bano and Sivaramakrishnan, 1980). Plants consider natural sources of both enzymes and they distinguish with their availability and safety as compared with microbes (Barbaree and Harless, 1995). Therefore, extraction of important enzymes such as L-asparaginase and L-glutaminase from plant sources are considered more safe and easier. There are many studies reported that neumerous plant species can produce L-asparaginase and L- glutaminase like Tamarindus indica, Capsicum annum (green and red chillies) and narrowleaf lupin (Lupinus angustifoliuos) (Bano and Sivaramakrishnan, 1980; Kiran et al., 2011). Ashwagandha or winter cherry (Withania somnifera), pole beans (Phaseolus vulgaris) and soybean root nodules have high specificity of enzyme L-asparaginase (Oza et al., 2009; Al Zobaidy et al., 2016; Liu et al., 2019). In addition, L-asparaginase was successfuly extracted from Phaseolus vulgaris seeds (Mohamed et al. 2015), Vigna unguiculata (Ali, 2009), Lupinus polyphyllus (Lea et al., 1984) and pea leaves (Sieciechowicz and Ireland, 1989).

\section{MICROALGAE}

L-asparaginase from blue-green microalgae is receiving more attraction, to its high cost-effectiveness, no seasonal variation, low cost of production nutrient contents, and to its high operative producers, can easily cultivate and harvested at large scale (Prihanto and Wakayama, 2016). L-asparaginase is the first such enzyme to be extracted form a marine microalgae Chlamydomonas sp. (Paul, 1982). Chlorella vulgaris, Spirulina maxima, and Phormidium formosum (Ebrahiminezhad et al., 2014; Abd El-Baky and El-Baroty, 2016; Elkomy and Farag, 2018) considered a novel microalgal source for L-asparaginase production. Also, cyanobacterium Oscillatoria Terebriformis can provide a rich source of L-asparaginase producing candidate (Elkomy, 2018).

\section{ENTRAPMENT IN ERYTHROCYTES}

Red cells using as micro-bioreactor; asparagine can enter in red cells by reversible osmotic lysis from surrounding medium (Young et al., 2009). Effect of 
anti-L-asparaginase antibodies can be overcome to the protection given by erythrocytes membrane to L-asparaginase so reduction of hypersensitivity and half-life increased. Also, human glycosyl asparaginase studied to its potentiality to hydrolysis of L-asparagine to L-aspartic and ammonia without L-glutaminase activity as L-asparaginase produced from bacteria so reduce associated side effect (Kelo et al., 2009; Young et al., 2009).

\section{PRODUCTION OF L-ASPARAGINASE AND L-GLUTAMINASE}

Several methods designed for the production and optimization of L-asparaginase and L-glutaminase from various microorganisms in solid state fermentation (SSF) and submerged fermentation (SmF) also in batch and continuous fermentation. Most of the microbial amidases examined are intracellular in nature while few are extracellular. Purification of intracellular asparaginases is tiresome (hard) as compared to extracellular enzymes. Production and optimization conditions differ from one organism to another, and L-asparaginase and Lglutaminase can be produced constitutively or after induction (Ahmad et al., 2012). Production of L-asparaginase and L-glutaminase depends on various parameters like the concentration of carbon and nitrogen sources, $\mathrm{pH}$ of culture medium, temperature, fermentation time and oxygen transfer rate also these parameters differentiate from one organism to another (Vidhya et al. 2010). Lasparaginase and L-glutaminase are mostly obtained by SmF. Many researchers have studied amidases production and purification and try to reduce the impurities that cause allergenic reactions (Ahmad et al., 2012; Ebrahiminezhad et al., 2014; Sinha and Nigam, 2016).

\section{THE NUTRITIONAL REQUIREMENTS AND CULTURE CONDITIONS}

The nutritional requirements and culture conditions for biosynthesis of amidases differ from one microorganism to another (Table 1, 2). It was observed that maximum L-asparaginase activity by Serratia marcescens ATCC 60 at $4 \%(\mathrm{w} / \mathrm{v})$ of Autolyzed Yeast Extract (AYE) medium compared with a complete dehydrated medium, corn steep liquor, and protein hydrolysate. Different carbon sources at $0.4 \%(\mathrm{w} / \mathrm{v})$ added to the basal medium was studied and the enzyme production for each one was compared and depression effect was to lower $\mathrm{pH}$ of fermentation of carbohydrate (Vidhya et al., 2010). Also, in media containing $0.05 \%(\mathrm{w} / \mathrm{v})$ yeast extract, no yield was observed. It was found that, complete inhibition of the growth of cells and enzyme production when $3 \%(\mathrm{w} / \mathrm{v})$ yeast extract was used (Liu and Zajic, 1973). Glucose gives maximum enzyme activity rather than maltose in case of Bacillus sp (Vidhya et al., 2010). In another study, glucose found to have an inhibition effect on the synthesis of Lasparaginase in Serratia marscences, Erwinia carotovora, Escherichia coli, Erwinia aroideae to catabolic suppression (Peterson and Ciegler, 1972; Vidhya et al., 2010). Other studies also showed that, a significant reduction in asparaginase activity when glucose was added to $3 \%$ nutrient broth and $1 \%(\mathrm{w} / \mathrm{v})$ of monosodium glutamic acid (Barnes $\boldsymbol{e t}$ al., 1978). Recently addition of $0.1 \%$ (w/v) glucose stimulates L-asparaginase activity compared to glucose-free medium and $1 \%(\mathrm{w} / \mathrm{v})$ glucose had a complete inhibition effect (Geckil and Gencer, 2004). Yeast extract and lactose also have a critical role in enzyme activity not only for growth. It's observed that yeast extract $1.5 \%(\mathrm{w} / \mathrm{v}), 1.0 \%$ (w/v) lactose have maximum enzyme production (Liu and Zajic, 1973). Also, it was demonstrated that $0.16 \%$ (w/v) of di-ammonium hydrogen phosphate and $1.0 \%(\mathrm{w} / \mathrm{v})$ sodium citrate have the maximum L-asparaginase activity in Enterobacter aerogenes and there was no intracellular asparaginase activity with sodium citrate (Mukherjee et al., 2000). Addition of $1.0 \%$ tryptone has maximum L-asparaginase activity. Similarly, supplementing asparagine, as the sole source of nitrogen, $E$. coli was able to grow and produce an enzyme (Cedar and Schwartz, 1967). It has shown a high yield of L-asparaginase from actinomycetes, Streptomyces griseus ATCC 10137 when growing on medium yeast malt glucose, $4.0 \%$ peptone without glucose and synthetic glucoseasparagine (Peter, 1972).

Bacterial asparaginases in long term of use cause hypersensitivity, anaphylaxis, and allergic reactions. So attention going to eukaryotic microorganisms producing L-asparaginase with fewer side effects especially filamentous fung and yeast (Sarquis et al., 2004). Saccharomyces cerevisiae was reported as nitrogen-regulated (Oliveira et $\boldsymbol{a l}$., 2003). Several studies were achieved by changing different nitrogen sources in media compassion for L-asparaginase production from Aspergillus terreus and Aspergillus tamari (Sarquis et al., 2004). The medium used for the fungal and soil bacteria is modified Czapeks medium which include glucose $0.2 \%(\mathrm{w} / \mathrm{v})$ and $1.0 \% \mathrm{~L}$-asparagine $(\mathrm{w} / \mathrm{v})$ for fungi while $0.5 \%(\mathrm{w} / \mathrm{v})$ for bacteria (Gulati $\boldsymbol{e t}$ al., 1997). Several researchers showed the production of recombinant L-asparaginase and give maximum enzyme activity from maltose, yeast extracts peptone and beef extract as a sole source of carbon and nitrogen (Maria et al., 2006). Many of microorganisms can utilize L-glutamine as carbon and nitrogen sources and produce L-glutaminase, it was reported that addition of glucose enhanced the enzyme production in Candida nodaensis (Sato et al., 1999), Beauveria sp. (Sabu et al., 2000) Pseudomonas sp. (Kumar and Chandrasekaran, 2003), Trichoderma koningii (El-Sayed, 2009) and Providencia sp. (Iyer and Singhal, 2009). While glucose addition can suppress production of L-glutaminase production from
Achromobacteraceae (Roberts et al., 1972) and Stenotrophomonas maltophilia NYW-81 (Wakayama et al., 2005). Addition of sorbitol for Beauveria bassiana BTMF S10 and sucrose for Zygosaccharomyces rouxii plus glucose enhance Lglutaminase production (Keerthi et al., 1999). The maximum enzyme production enhanced by glucose followed by lactose and maltose when using different carbon sources like glucose, lactose, sucrose, soluble starch, maltose, and fructose at $1.0 \%(\mathrm{w} / \mathrm{v})$ in the medium of $A$. oryzae. Organic nitrogen sources more preferable than inorganic sources in production media for L-glutaminase producing microorganisms. It was noticed that $S$. rimosus (Wakayama et al., 2005) utilize malt extract and give maximum L-glutaminase production while $C$. nodaensis (Sato et al., 1999), B. bassiana BTMF S10 (Keerthi et al., 1999) and $Z$. rouxii (Iyer and Singhal, 2010) can utilize yeast extract and give high yield. Providencia sp. and Achromobacteraceae use urea and ammonium sulfate respectively, improved the enzyme production (Roberts et al., 1972). The Lglutaminase production was improved by a seawater-based medium supplemented with L-glutamine $(0.25 \%)$ (Sabu et al., 2000). For the determination of amidases activities by semi-quantity plate assay $\mathrm{pH}$ play a major role (Peter, 1972). In this assay phenol red as a $\mathrm{pH}$ indicator which is yellow at the acidic condition and turns to Pink at the alkaline condition. L-asparagine or L-glutamine used as a sole nitrogen source and $\mathrm{pH} 5.5$ to 7.0 (Gulati et al. 1997). Temperature is one of the main process parameters for the enzymes production. It was shown that Erwinia aroideae (Liu and Zajic, 1973), Citrobacter sp. and Serratia marcescens ATCC 60 (Vidhya et al., 2010) needs optimum temperature for production L-asparaginase ranges between $25^{\circ} \mathrm{C}$ and $37{ }^{\circ} \mathrm{C}$ and $\mathrm{pH} 5.0$ while for vibrio $\mathrm{pH}$ 8.0. Maximum enzyme production is obtained after 24h from Erwinia aroideae NRRL B-138 (Peterson and Ciegler, 1972) and $48 \mathrm{~h}$ in shake flask from Serratia marcescens ATCC (Geckil and Gencer, 2004). The purified enzyme tested from Serratia marcescens and E.coli has shown low response when compared with Erwinia aroideae NRRL B-138 (Peterson and Ciegler, 1969). It has been observed that, the maximum enzyme production from Thermus thermophilus $\mathrm{HB} 8$ at $70{ }^{\circ} \mathrm{C}$ and $\mathrm{pH} 7.0$ (Prista and Kyridio, 2001). Erva (2018) reported the maximum temperature and $\mathrm{pH}$ for $\mathrm{L}$ asparaginase production from Bacillus subtilis was $49.9{ }^{\circ} \mathrm{C}$ and 8.3 while in another study by Jia et al. (2013) the maximum production from $B$. subtilis B11-06 at $40{ }^{\circ} \mathrm{C}$ and 7.5, respectively. While Vidhya et al. (2010) reported that optimum $\mathrm{pH}$ was 7.0 and temperature was $37{ }^{\circ} \mathrm{C}$ from Bacillus sp. The optimum incubation temperature and $\mathrm{pH}$ values for L-glutaminase production were reported by Sinha and Nigam (2016) from Bacillus sp. at $35^{\circ} \mathrm{C}$ and 7.0. In the case of recombinant L-asparaginase production, the optimum temperature and $\mathrm{pH}$ are $28-30{ }^{\circ} \mathrm{C}$ and $\mathrm{pH}$ 6.0-7.0, respectively (Maria et al., 2006). In order to minimize hypersensitivity produced by bacterial L-asparaginase, the study of eukaryotic microorganisms for L-asparaginase with fewer side effects were focused (Sarquis et al., 2004). Many researchers studied the production of Lasparaginase from Saccharomyces cerevisiae (Oliveira et al., 2003). Maximum enzyme activity of Aspergillus tamari and Aspergillus terreus $10 \mathrm{C} 217$ observed at an optimum pH 6.2 at $30{ }^{\circ} \mathrm{C}$ for $48 \mathrm{~h}$ (Sarquis et al., 2004). Few studies are available on the actinomycetes species, Streptomyces sp. named S3 shown optimum enzyme activity at fermentation conditions of pH 7.5 at $50{ }^{\circ} \mathrm{C}$ (Saleem et al., 2009). L-glutaminase production also affected by $\mathrm{pH}$ and temperature and each organism has optimum $\mathrm{pH}$ and temperature. It was reported that Pseudomonas sp. has a maximum activity for L-glutaminase at $37^{\circ} \mathrm{C}$ and $\mathrm{pH} 7.0$ (Roberts, 1976). Whereas, L-glutaminases produced from marine Micrococcus luteus have maximum activity at high-temperature $50^{\circ} \mathrm{C}$ and at alkaline $\mathrm{pH} 8.0$ to 8.5 (Moriguchi et al., 1994). Also, it was reported that glutaminase from Aspergillus oryzae has $\mathrm{pH}$ optima of 8.0 to 9.0 while optimum temperature from $37^{\circ} \mathrm{C}$ to $45^{\circ} \mathrm{C}$ (Koibuchi et al., 2000). L-glutaminase produced from Penicillium brevicompactum NRC 829 exhibited its maximal activity when incubated at 50 ${ }^{\circ} \mathrm{C}$ and at $\mathrm{pH} 8.0$ (Elshafei et al., 2014).

\section{EFFECT OF METAL IONS, ACTIVATORS, INHIBITORS, AND SALT TOLERANCE}

L-asparaginase and L-glutaminase activity differed in the existence of enhancers or enzyme inhibitors. To study the synergistic effect on the amidases production it was found that metal ions as $\mathrm{Fe}^{3+}, \mathrm{Ni}^{2+}$ and $\mathrm{Fe}^{2+}, \mathrm{Mg}^{2+}, \mathrm{Zn}^{2+}$ and $\mathrm{Cu}^{2+}$, and $\mathrm{Hg}^{2+}$ had inhibitory effect on enzyme activity (Saleem $\boldsymbol{e t}$ al., 2009) and also activity inhibited in the presence of thiol-group-blocking reagents such as iodoacetamide and p-chloromercuribenzoic acid (PCMB). Activity was enhanced by the addition of amino acids as L-histidine and L-cysteine, EDTA and some reducing agents like dithiothreitol (DTT), 2-mercaptoethanol (2-ME), and reduced glutathione (GSH) (Vidhya et al., 2010). All of these results specified that L-asparaginase is not a metalloprotein. Therefore, the sulfhydryl group has an important role in the catalytic activity of L-asparaginase (Gaffar and Shethna, 1977).

L-asparaginase from Azotobacter vinelandii has high sensitivity to heavy-metal ions N-ethylmaleimide and iodoacetate also demonstrated the reliance of the activity of the enzyme upon sulfhydryl group (Gaffar and Shethna, 1977). Marine Bacillus sp. have maximum enzyme production by addition of $2.0 \%$ (w/v) $\mathrm{NaCl}$ which has comparatively high ability compared to other concentrations (Mohapatra et al., 1995), while, E.coli has better salt tolerance up to $5.0 \%(\mathrm{w} / \mathrm{v})$ but has no effect on enzyme production (Cedar and Schwartz, 
1967). Many researchers have shown that bacterial L-glutaminase was stimulated by certain divalent ions and inhibited by monovalent anions and by some competitive inhibitors like 6-diazo 5-oxo L-nor leucine, L-glutamate, and $\mathrm{NH}_{3}$ (Soda $\boldsymbol{e t}$ al., 1972). In the case of fungal L-glutaminase produced from Aspergillus oryzae and P. brevicompactum was inhibited by $\mathrm{Hg}^{2+}, \mathrm{Cr}^{+2,}$ and $\mathrm{Fe}^{+2}$ but were not affected by sulphydroxyl reagents while $\mathrm{Na}^{+}$or $\mathrm{K}^{+}$act as enhancers (Kumar and Chandrasekaran, 2003; Elshafei et al., 2014). It has been found that EDTA has no effect on enzyme activity which indicates that L-glutaminase might not be a metalloenzyme also not affected by thiol-blocking group, reducing agents as 2-ME and GSH so no indication for the participation of SH group(s) in the catalytic site of this enzyme (Elshafei et al., 2014). Sodium chloride was found to influence the activity of microbial glutaminase. L-glutaminase from $A$ sojae, $P$. fluorescence, Cryptococcus albidus and E.coli in presence of $18 \% \mathrm{NaC}$ showed only 6, 75, 65 and $65 \%$ respectively of their original activity (Yokotsuka et al., 1987). On the other hand, L-glutaminases may be inhibited by high salt concentrations (Sabu et al., 2000).

\section{RECOMBINANT PRODUCTION OF L-ASPARAGINASE AND L- GLUTAMINASE}

Although several native L-asparaginase and L-glutaminase were produced from bacteria, fungi, actinomycetes, and plants, few studies on the heterologous expression of recombinant L-asparaginase and L glutaminase (Wakayama et al. 2005; Shakambari et al., 2019 ). Vidya and Vasudevan (2011), Shakambari et al. (2019) reported that $E$. coli has two types of L-asparaginases by notably different properties, known as L-asparaginase I and II. Type I is cytoplasmic and has a low affinity for L-asparagine and produced constitutively. While the type II is periplasmic and has a high-affinity for L-glutaminase and its expression is positively regulated by different inducers as the cyclic AMP receptor protein and anaerobiosis (Fumarate and Nitrate Reductase FNR protein) so attract great importance in anticancer treatment. When studying the L-asparaginase genetics, revealed that the sequences of coding genes are different, and ansA encodes for type I while gene ansB encoding type II. Also, efforts to cloning ansB and overexpression of L-asparaginase successfully performed and resulted in the production of L-asparaginase II. On the other hand, L-glutaminases members tend to be designated as glutaminase A (glsA), where B (glsB) is unknown and may not be homologous (as in Rhizobium etli) some species have two isozymes that may both be designated A (glsA1 and glsA2) (Botman et al., 2014). Fisher and Wray (2002) reported L-asparaginase from B. subtilis regulated by two various controlled genes and their expression regulated by independent regulative factors. The ansZ gene encodes a functional L-asparaginase which expression activated by the TnrA transcription factor during nitrogen-limited growth through binding to a DNA site that lies upstream of the ansZ promoter. And, the ansA gene encodes another L-asparaginase and its expression effected by L-asparagine In an operon, ansA gene located with ansB gene encodes L-aspartase. The expression of the ans AB operon hindered by AnsR which activity monitored by either L-aspartate or L-asparagine. In another hand, for recombinant glutaminases isolated from B. subtilis (ylaM and ybgJ genes) and from E. coli (ybaS and yneH genes), tested the biochemical characterization of the four L-glutaminases and determined the crystal structures of Ybg and YbaS (Brown et al., 2008). Also, GlsA gen from B. licheniformis expressed in E. coli, under the effective control of the promoter Ptac (Sinsuwan et al., 2012). Another study in production recombinant glutaminases. Calderon et al. (1999), Huerta-Saquero et al. (2001) reported the sequencing gene codes of Rhizobium etli thermolabile glutaminase A (glsA) and expressed in the heterologous host Sinorhizobium meliloti and in expression vector pTrcHis. while L-glutaminase gen from $A$. oryzae RIB40 (AoglsA) expressed heterologously in $S$. cerevisiae and E. coli and the expressed enzyme showed glutaminase activity and was produced in a soluble protein in $E$. coli and a cell wall fraction of $S$. cerevisiae (Masuo et al., 2004) Ito et al. (2011, 2012) isolate and cloned novel glutaminases genes CagahA and CngahA and AsgahA from Cryptococcus albidus and Cryptococcus nodaensis and $A$. sojae. The expression of L-glutaminase activity was enhanced by the introduction of multiple copies of AsgahA into A. oryzae RIB40. The gene coded AsgahA secreted at the cell surface in submerged culture, and extracellularly in solid-state culture. Jia et al. (2013) reported cloning L-asparaginase ansZ gene from B. subtilis B11-06 a non-pathogenic strain and its overexpression and purification of the thermostable protein was performed. Also, cloning of the gene Tk1656 coding L-asparaginase of Thermococcus kodakarensis KOD1 achieved in E. coli BLR (DE3) (Hong et al., 2014). El-Gendy et al. (2017) studied cloning and protoplast fusion of filamentous fungi glutaminases gen such as Cladosporium sp. (gen 20) and Trichoderma sp. (gen 9) and screened for Lglutaminase production. The recombinant L-asparaginase and L-glutaminase fortunately over-expressed and purified. Thus recombinant DNA technologies have been applied successfully to yield many folds increased L-asparaginase and L-glutaminase production and to maintain enhanced properties of activity and stability (Binod et al., 2017; Shakambari et al., 2019). The list of organisms whose genes cloned for L-glutaminase and L-asparaginase overexpression listed in Table 3.

Table 1 Summary of fermentation conditions for the production of L-asparaginase and L-glutaminase by submerged fermentation (SmF)

\begin{tabular}{|c|c|c|c|c|c|}
\hline Microorganisms & $\begin{array}{c}\text { Enzyme } \\
\text { produced }\end{array}$ & $\begin{array}{c}\text { Nutrition } \\
\text { requirements \% (w/v) }\end{array}$ & $\begin{array}{c}\text { Fermentation } \\
\text { conditions }\end{array}$ & Activity & References \\
\hline $\begin{array}{l}\text { Serratia marcescens } \\
\text { ATCC } 60\end{array}$ & LAase & AYE 4.0 & $\mathrm{pH} 5.0,26^{\circ} \mathrm{C}, 48 \mathrm{~h}$ & $3.7 \mathrm{U} / \mathrm{ml}$ & $\begin{array}{l}\text { (Heinemann and Howard, } \\
\text { 1969) }\end{array}$ \\
\hline $\begin{array}{l}\text { Enterobacter } \\
\text { aerogenes NCIM } 2340\end{array}$ & LAase & $\begin{array}{l}\text { Sodium citrate } 1.0, \text { di- } \\
\text { ammonium hydrogen } \\
\text { phosphate } 0.16\end{array}$ & $\mathrm{pH} 7.0,37^{\circ} \mathrm{C}, 24 \mathrm{~h}$ & $0.60 \mathrm{U} / \mathrm{ml}$ & (Mukherjee et al., 2000) \\
\hline $\begin{array}{l}\text { Erwinia aroideae } \\
\text { NRRL B-138 }\end{array}$ & LAase & $\begin{array}{l}\text { Tryptone } 0.05, \text { Yeast } \\
0.05 \text {, glucose } 0.1\end{array}$ & $\begin{array}{c}\text { 2.8L flasks: } \\
\mathrm{pH} 7.0,28^{\circ} \mathrm{C}, 200 \mathrm{rpm}, \\
8 \mathrm{~h} \\
20 \mathrm{~L} \text { fermenter: } \\
\mathrm{pH} 7.0,28^{\circ} \mathrm{C}, 24 \mathrm{~h}, 300 \\
\text { rpm. }\end{array}$ & $\begin{array}{l}1250 \mathrm{U} / \mathrm{ml} \\
960 \mathrm{U} / \mathrm{ml}\end{array}$ & $\begin{array}{l}\text { (Peterson and Ciegler, } \\
\text { 1969) }\end{array}$ \\
\hline $\begin{array}{l}\text { Bacillus sp. } \\
\text { DKMBT10 }\end{array}$ & LAase & $\begin{array}{l}\text { L-Asparagine } 0.6 \text {, } \\
\text { glucose/maltose } 0.3\end{array}$ & $\begin{array}{c}\mathrm{pH} 7,37^{\circ} \mathrm{C}, 200 \mathrm{rpm}, 24 \\
\mathrm{~h}\end{array}$ & $1.12 \mathrm{U} / \mathrm{ml}$ & (Vidhya et al., 2010) \\
\hline Bacillus pumilus & LAase & $\begin{array}{c}\text { Galactose } 2.0 \text {, asparagine } \\
0.1\end{array}$ & $28-30^{\circ} \mathrm{C}, 100 \mathrm{rpm}, 48 \mathrm{~h}$ & $75.73 \mathrm{U} / \mathrm{ml}$ & $\begin{array}{l}\text { (Sindhwad and Desai, } \\
\text { 2015) }\end{array}$ \\
\hline $\begin{array}{l}\text { Pseudomonas } \\
\text { aeruginosa } 50071\end{array}$ & LAase & $\begin{array}{c}\text { Soya bean meal } 5.0 \mathrm{~g} / 1 \text {, } \\
\text { Inducers- casein } \\
\text { hydrolysate } 3.11 \mathrm{~g} / \mathrm{l} \text {, corn } \\
\text { steep liquor } 3.68 \mathrm{~g} / \mathrm{l} \text {. }\end{array}$ & $\mathrm{pH} 7.4,37^{\circ} \mathrm{C}, 96 \mathrm{~h}$ & $1.428 \mathrm{U} / \mathrm{ml}$ & (Yasser and Olama, 2002) \\
\hline $\begin{array}{l}\text { Pseudomonas sp } \\
\text { BTMS-51 }\end{array}$ & LGase & $\begin{array}{l}\text { L-glutamine } 2.0, \mathrm{D}- \\
\text { glucose } 1.0\end{array}$ & $\mathrm{pH} 6,30^{\circ} \mathrm{C}$ & $21.07 \mathrm{U} / \mathrm{ml}$ & $\begin{array}{l}\text { (Kumar and } \\
\text { Chandrasekaran, 2003) }\end{array}$ \\
\hline Vibrio SP. & LGase & M9 & $\mathrm{pH} 7,35^{\circ} \mathrm{C}$ & $28.7 \mathrm{U} / \mathrm{ml}$ & (Saravanan et al., 2014) \\
\hline Vibrio azureus JK-79 & LGase & $\begin{array}{c}\text { glutamine } 2.0, \text { soybean } \\
\text { meal } 2.0, \text { maltose } 1.5 \\
\end{array}$ & $\mathrm{pH} 8,37^{\circ} \mathrm{C}$ & $321 \mathrm{U} / \mathrm{ml}$ & $\begin{array}{l}\text { (Kiruthika and } \\
\text { Nachimuth, 2013) } \\
\end{array}$ \\
\hline Providencia sp & LGase & Glucose 1.0 and urea 0.5 & $\mathrm{pH} 8,25^{\circ} \mathrm{C}$ & $119.23 \mathrm{U} / 1$ & (Iyer and Singhal, 2009) \\
\hline $\begin{array}{l}\text { Stenotrophomonas } \\
\text { maltophiliaNYW-81 }\end{array}$ & LGase & L-Glutamine 1.0 & $\mathrm{pH} 7,30^{\circ} \mathrm{C}$ & $3.25 \mathrm{U} / \mathrm{mg}$ & (Wakayama et al., 2005) \\
\hline $\begin{array}{l}\text { Aspergillus } \\
\text { terreusIOC } 217\end{array}$ & LAase & Proline 2.0 & $\begin{array}{c}\mathrm{pH} 6.2,30^{\circ} \mathrm{C} 48 \mathrm{~h}, 160 \\
\text { rpm. }\end{array}$ & 0.058 & (Sarquis et al.,2004) \\
\hline Pichia pastoris & LAase & BSM2 & $(2 \mathrm{~L})$ flask: $\mathrm{pH} 5.0,30^{\circ} \mathrm{C}$ & 85.6 & (Maria et al., 2006) \\
\hline
\end{tabular}




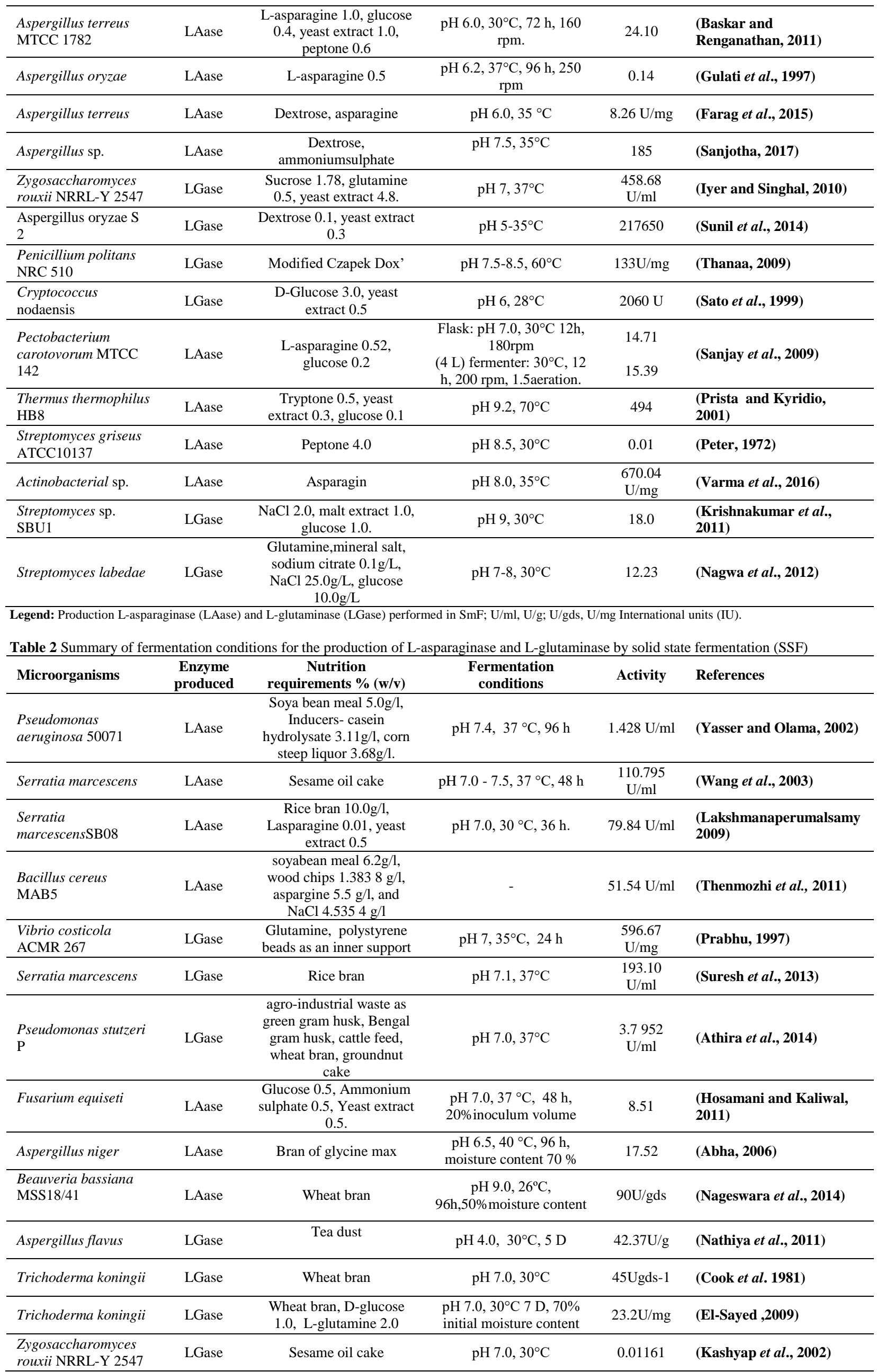




\begin{tabular}{|c|c|c|c|c|c|}
\hline $\begin{array}{l}\text { Aspergillus sp. } \\
\text { ALAA-2000 }\end{array}$ & LGase & Soybean & $\mathrm{pH} 4$ and $27^{\circ} \mathrm{C}$. & 21.89 & (Ahmed et al., 2016) \\
\hline $\begin{array}{l}\text { Aspergillus wentii } \\
\text { MTCC } 1901\end{array}$ & LGase & $\begin{array}{c}\text { L-glutamine } 3.0, \text { sucrose } \\
4.0 \text {, peptone } 2.0, \\
\text { magnesium sulphate } 1.0\end{array}$ & $\begin{array}{l}\mathrm{pH} 8.0,32^{\circ} \mathrm{C}, 96 \mathrm{~h}, 40 \% \\
\text { initial moisture }\end{array}$ & $\begin{array}{l}259.32 \\
\mathrm{U} / \mathrm{gds}\end{array}$ & (Revanth and Raju, 2013) \\
\hline $\begin{array}{l}\text { Aspergillus Wentii } \\
\text { MTCC } 1901\end{array}$ & LGase & Peptone & $\begin{array}{l}\mathrm{pH} 6.8,30^{\circ} \mathrm{C}, 144 \mathrm{~h}, \\
45 \% \text { moisture content }\end{array}$ & $\begin{array}{l}703.83 \\
\text { U/gds }\end{array}$ & (Durgasi and Raju, 2016) \\
\hline $\begin{array}{l}\text { Beauveria sp. BTMFS } \\
10\end{array}$ & LGase & $\begin{array}{l}\text { L-glutamine } 0.25, \\
\text { Polystyrene beads as inner } \\
\text { support,D-glucose } 0.5\end{array}$ & $\mathrm{pH} 9.0,27^{\circ} \mathrm{C}$ & 49890.00 & (Sabu et al., 2000) \\
\hline
\end{tabular}

Table 3 Recombinant production of L-asparaginase and L-glutaminase from microbial origin

\begin{tabular}{|c|c|c|c|}
\hline Recombinant enzyme & $\begin{array}{c}\text { Microbial sources of the } \\
\text { foreign gene }\end{array}$ & Host cell & Reference \\
\hline RGase & Rhizobium etli & E. coli & (Huerta-Saquero et al. ,2001) \\
\hline RAase & A. oryzae & S. cerevisiae and E. coli & (Masuo et al., 2004) \\
\hline RAase & E. chrysanthemi & E. coli BL21(DE3) pLysS & (Kotzia and Labrou, 2007) \\
\hline RGase & Cryptococcus sp. & S. cerevisiae & (Ito et al., 2011) \\
\hline RAase & $\begin{array}{l}\text { S. thermoluteus subsp. fuscus } \\
\text { NBRC } 14270\end{array}$ & S. lividans 1326 & (Hatanaka et al., 2011) \\
\hline RGase & B. licheniformis & E. coli & (Sinuswan et al., 2012) \\
\hline RAase & E. sp. NII & E. coli BL21(DE3) & (Vidya and Pandey, 2012) \\
\hline RGase & A. sojae & A. sojae & (Ito et al., 2012) \\
\hline RAase & B. subtilis B11-06 & B. subtilis & (Jia et al., 2013) \\
\hline RAase & V. cholera & E. coli BL21 (DE3) & (Radha et al., 2018) \\
\hline
\end{tabular}

Legend: Production Recombinant L-asparaginase (RAase) and Recombinant L-glutaminase (RGase)

\section{L-ASPARAGINASE AND L-GLUTAMINASE ASSAY METHODS}

Several techniques developed and reported to assay L-asparaginase and Lglutaminase activities. L-asparaginase and L-glutaminase activities determined by estimating the amount of ammonia or acids liberated through the reaction due to their hydrolysis of asparagine and glutamine, respectively. The quantitative and qualitative techniques employed for the measuring of $\mathrm{L}$-asparaginase and $\mathrm{L}$ glutaminase activities. In the quantitative methods, rapid plate assay, a $\mathrm{pH}$ indicator incorporated medium containing $\mathrm{L}$-asparagine or $\mathrm{L}$-glutamine as sole nitrogen source with the addition of a $\mathrm{pH}$ indicator. The activities of $\mathrm{L}$ asparaginase and L-glutaminase characterized by an increase in $\mathrm{pH}$ because of the liberation of ammonia (Gulati et al., 1997). Gulati et al. (1997) stated phenol red indicator as $\mathrm{pH}$ indicator while Mahajan et al. (2012) used bromothymo blue (BTB) as pH indicator instead of phenol red in rapid plate assay detection. In the quantitative assay of L-asparaginase and L-glutaminase concern with the detection of ammonia liberated when the reaction catalyzed by L-asparaginase and L-glutaminase on their natural substrate $\mathrm{L}$-asparagine and L-glutamine, respectively (El-Naggar, 2015; Tork et al., 2018). Briefly, the Nesslerization assay includes the cell lysate (intracellular) or the crude enzyme supernatant (extracellular) incubated with the substrate for 10 mins, and after incubation, the reaction stopped by addition of trichloroacetic acid (TCA). After that, the liberated ammonia examined by addition of Nessler's reagent in the diluted enzyme substrate mixture and formation of the yellow color due to the presence of ammonia which used quantitatively for determining the enzyme activity. One unit of enzyme activity defined as the amount of enzyme that produces $1 \mu \mathrm{mol}$ of ammonia per minute at slandered reaction condition $\left(\mathrm{pH} 8.6\right.$ and $\left.37^{\circ} \mathrm{C}\right)$. There are additional methods for enzymes detection but plat assay and Nesslerization method is the most common (El-Sayed, 2009; Vidhya et al., 2010).

\section{APPLICATION OF L-ASPARAGINASE AND L-GLUTAMINASE}

\section{IN MEDICINE}

Regulation of cancer cells can be reached by inhibition of nucleic acid and protein biosynthesis by the absence of any component of these macromolecules The World Health Organization (WHO) and Food and Drug Administration (FDA) have agreed that L-asparaginase is the most effective cure of lymphosarcoma and acute lymphoblastic leukemia (ALL). L-asparaginase hydrolyzes asparagine from blood serum, causing tumor death by removing a vital factor for protein synthetases (p53-dependent apoptosis). While Lasparagine synthetase found in adequate amounts in healthy cells so it not affected (Shakambari et al., 2019). L-asparaginase has been produced from variant sources but only from Erwinia and E. coli used on a manufacturing scale. While the two drugs have the same mode of action and toxicities, pharmacokinetic properties are altered and allergic to one drug are often resistant to the other (Dhanam and Kannan, 2013). Bhat and Marar (2015) reported Lasparaginase from Salinicoccus sp. MKJ997975 inhibited the growth of both Jurkat and HeLa cell line. While Shanmugaprakash et al. (2015) reported L- asparaginase from Capsicum annuum $\mathrm{L}$ showed maximum activity in the $\mathrm{KB}$ cell line, the least activity was found in A549 and moderate activity in HeLa cell lines by using. Moharib (2018) showed L-asparaginase has higher efficiency in growth inhibition against Hep-G2 and HCT-116 but lower against HeLa and MCF-7 carcinoma cell lines. Recently, Oza et al. (2010) reported Withania somnifera L-asparaginase in vitro has antitumor activity using the MTT method (this research proposed as the first report of plant asparaginases).

The modified type of the enzyme is PEG-asparaginase. PEG-asparaginase produced by covalently conjugate L-asparaginase and monomethoxy polyethylene glycol (PEG). Patients with hypersensitivity to native E. coli asparaginase, PEG-asparaginase is considered more effective. PEG-asparaginase reduces the immunogenicity of the protein, increases its stability in plasma and is suitable for use in heavily pretreated patients (Inada et al., 1995). Results showed that PEG-asparaginase successfully depleted the asparagine and acted as a part of an intensive multiagent healing system in adult acute lymphoblastic leukemia (Wetzler et al., 2007). Combination of L-asparaginase and ABT-737 induced mitochondrial cytochrome-C release, stimulation of Bax, Bid, better mitochondrial depolarization, and finally apoptosis neither drug alone (Kang et al., 2007). L-asparaginase brand names are KIDROLASE, ELSAPAR, ERWINASE, and ONCASPAR (El-Ghonemy, 2014). The medical utility of Lasparaginase is frequently restricted by the side effects including pancreatitis and immunosuppression (Wang et $\boldsymbol{a l}$., 2003), ten percent of patients suffer a relapse followed by occurrence of resistant tumors to further L-asparaginase therapy (Woo et al., 2000) and long term treatment with L-asparaginase increases the metastatic activity and develops the growth of resistant malignant tumor (Asselin et al., 1999). Recently the small molecule ABT-737 which inhibits and binds the $\mathrm{Bcl}-2$ family antiapoptotic proteins $\mathrm{BclW}, \mathrm{Bcl}-2$, and $\mathrm{Bcl}-\mathrm{XL}$ Erwinia asparaginase also have been used in combination with other chemotherapeutic agents as a therapy to hypersensitivity patients of a drug derived from $E$. coli (Dhanam and Kannan, 2013).

On the other hand, L-glutaminase inhibits uptake of glutamine (precursor for the nucleotide and protein synthesis) by cancer cells, so the growth stopped (Sarada, 2013). Many researches demonstrated L-glutaminase have an anticancer effect (Roberts et al., 1970; Spiers and Wade, 1976; Elshafei et al., 2014). The main problems associated in L-glutaminase treatment are the intravenous introduction had to act at the cancer location within the short span of time it persisted in circulation before cleared at the kidneys and the induction of immune responses against the enzyme. Many investigations are done to avoid these problems and found that L-glutaminase used in the treatment of the definite types of cancers. Spiers and Wade (1976) explain the difficulties occurred in clinical treatments of L-glutaminase as anti-leukemia. It has been shown that enzyme optimal activity over a wide $\mathrm{pH}$ range was obtained when immobilization of the $\mathrm{L}$ glutaminase in polyethylene glycol due to the matrix effect. The latter approach was the use of L-glutaminases in treatment Ehrlich ascites tumor (one type of breast carcinoma) (Lobo et al., 2000). Using MTT assay, L-glutaminase from Penicillium brevicompactum NRC 829 and Aspergillus niger effect on the growth of four human tumor cell lines A549 (Human lung carcinoma), MCF-7 (Breast cancer cell line), Hep-G2 (Human hepatocellular carcinoma cell line) and HCT116 (Colon cell line) revealed that L-glutaminase have antiproliferative action in 
four cell lines growth (Elshafei et al., 2014; Dutt $\boldsymbol{e t}$ al., 2014). L-glutaminases also are used in the treatment of melanoma (El-Ghonemy, 2014). By using MTT assay, Streptomyces canarius L-glutaminase tested against MCF-7, HepG-2, RAW264.7, HCT-116, and HeLa cells and the enzyme had a high cytotoxic effect against HeLa and HepG-2 cell lines, moderate HCT- 116 and RAW264.7 and no effect against MCF-7 cells (Reda, 2015). From that L-glutaminase concerning as a promising candidate for cancer therapy.

Some researchers showed that glutaminase-asparaginase enzyme from Achromobacter and Aspergillus niger have anticancer effects in patients with acute myeloid leukemia and acute lymphoblastic leukemia in a preliminary clinical experiment (Spiers and Wade, 1976, Elzainy et al., 2006). The most promising therapeutic applications for L-glutaminase is in the treatment of human immunodeficiency virus (HIV) where L-glutaminase from Pseudomonas sp. 7A is directed to inhibit HIV replication in infected cells (Kumar and Chandrasekaran, 2003). Sarada (2013) reported L-glutaminase lowers Lglutamine levels in serum and tissues for prolonged periods through decreasing reduction of serum reverse transcriptase activity of HIV.

\section{IN FOOD INDUSTRY}

L-glutaminase and L-asparaginase are the most important enzymes used in food manufacture for their hydrolysis glutamine and asparagine to glutamic and aspartic acid. Glutamic and aspartic acid are two important amino acids in food processing for a delicious and fine taste, Sour and Umami taste and nutritional important to food (Nanda et al., 2003). The palatable and pleasant flavors of oriental fermented foods as sufu, soy sauce and miso are due to the content of Lglutamic acid in it. In addition, aspartic acid decarboxylase catalyzes the conversion of aspartic acid into alanine, an influential amino acid constituent of soy sauce. Also, the additions of bacterial glutaminase or to the fermentation process increase the amount of glutamine so improve the umami taste of soy sauce (Kijima and Suzuki, 2007). Where there is increase about of glutamic acid in soy sauce made by the addition of glutaminase from Cryptococcus albidus ATCC 20293 (Binod et al., 2017). L-glutaminase from Koji mold is highly active so used for increasing the L-glutamate concentration of soy sauce (Yamamoto and Hirooka, 1974). In the Japan Tokko Koho Company, to improve the flavor of soy sauce they used peptide glutaminase of B. circulans (Hamada and Mashall, 1988). For improving Ushijima and Nakadai used protoplast fusion and mutation techniques for L-glutaminase production by A. sojae used in shoyu fermentation (Kikuchi and Sakaguchi, 1973). Industrial processes of glutamine to glutamate in food preparations either immobilized L-glutaminase or whole cells of L-glutaminase require high salt environments as in the fermentation of soy sauce. L-glutaminases from $A$. oryzae are inhibited by high salt concentrations. Salt tolerant L-glutaminases are patent for use in manufacturing manners (Sabu et al., 2000). Therefore, it is not unexpected that L-glutaminase is studied as a catalyst for the processing of fermented condiments as Japanese soy sauce (Wakayama et al., 2005). Glutaminases from salt tolerant bacteria are most interesting, L-glutaminase from halophilic rather than halotolerant tolerating for the use of high salt concentrations (Moriguchi et al., 1994). On the other hand the ability of L-asparaginases to hydrolyze asparagine into L-aspartate and ammonia is a possible way to decrease the amount of free $\mathrm{L}$-asparagine in the preliminary ingredients of food making, thus minimize the imminent risk of causing neurotoxic and carcinogenic compound an odorless and colorless crystalline solid, acrylamide (2-propenamide) which formed from reducing sugars and L-asparagine in carbohydrate-containing foods when they are heated above $120^{\circ} \mathrm{C}$ as a result of Millard reaction (Mottram et al., 2002). Acrylamide formation decreased about $96-99 \%$ in the products when raw materials pretreated by L-asparaginase before thermal treatment (Lindsay and Jang, 2005; Morales et al., 2008). The brand names of L-asparaginase as a processing aid in the manufacture of food are Prevent ASe and Acrylaway (EL-Ghonemy, 2014) Recombinant L-asparaginase Novozymes A/S Denmark (submitted by Novozymes Australia Pty Ltd) used as a food processing aid (Pedreschi $\boldsymbol{e t}$ al. 2008). Hendriksen et al. (2009) reported the reduction in acrylamide content was 34-92\% when recombinant asparaginase from Aspergillus oryzae tested on different food samples (French fries, ginger biscuits, crisp bread, semisweet biscuits, and sliced potato chips).

\section{ANALYTICAL APPLICATION}

The biosensor technology can be a user-friendly approach, cheap, and reliable. Lasparaginase and L-glutaminase are used for the development of biosensor applications. Enzymatic determination of asparagine, aspartate, glutamine, and glutamate are more reliable and accurate compared to the older methods like Nesslerization followed by determination of liberated ammonia. The mechanism of action of the biosensor is based on L-asparaginase activity, ammonium ions produced from the hydrolysis of asparagine cause a change in $\mathrm{pH}$ resulting in the change of color and absorption (Kumar et al., 2013). L-asparaginase is used to analyze asparagine levels either in the food industry or leukemia (Verma $\boldsymbol{e t}$ al. 2012). Many spectroscopy techniques such as Transmission electron microscopy (TEM), X-ray photoelectron spectroscopy (XPS), X-ray diffraction (XRD), and scanning electron microscope (SEM) are recently used for L-asparagine analysis, but tedious procedures and high cost make them less favorable (Zubavichus $\boldsymbol{e}$ al., 2004). Nowadays analyses of levels of the body fluids as L-glutamine and glutamate are vital in health monitoring and clinical diagnostics. L-glutaminases biosensors are used immobilized on membranes or in free enzyme forms for monitoring glutamine and glutamate concentration (Unissa et al., 2014; Binod et al., 2017). Currently, researches are going to search for the most stable forms for a longer period of using in biosensors, and plants are ongoing to manufacturing highly purified L-glutaminase enzyme definitely for that aim (Binod et al., 2017). Although the main L-glutaminases clinically used came from mammalian sources with little exceptions, the Kikkoman Corporation (Japan) deal with L-glutaminase in clinical studies from microbial source especially Bacillus sp. and used it with conjunction with L-glutamate oxidase and peroxidase for determination of glutamine (Sabu et al., 2000). L-glutaminase based biosensors have been used for investigation of glutamine and glutamate in pharmaceutical formulations, in hybridoma culture media by flow injection analysis and in the monitoring of glutamine and glutamate levels in mammalian cell culture media (Huang et al., 2006; Sarada, 2013). On the other hand, free enzyme form has been used in the determination of glutamine in media of insect cell culture (Meyerhoff et al., 1995). Important applications of L-glutaminase based biosensors are using in the online monitoring of fermentation (Wang et al., 2010).

\section{MANUFACTURE OF FINE-CHEMICALS}

L-asparaginases and L-glutaminases play a vital role in the biosynthesis of finechemicals. L-asparaginase is incorporated in the production of the aspartic family of amino acids such as methionine, lysine, and threonine. Aspartic acid, that is considered as a precursor of lysine and threonine is formed by L-asparaginase enzyme hydrolysis of asparagine (Sinha et al., 2013). One of the most vital submissions of L-glutaminase in the industry is using it in the production of $\gamma$ glutamyl alkamides. Theanine ( $\gamma$-l-glutamyl ethylamide) is a product result from transfer $\gamma$-glutamyl from glutamine or glutathione to a glutamyl acceptor as glycylglycine, methylamine or ethylamine. Theanine is unique as a tasteenhancing amino acid in Japanese infused green tea. In recent times, more attention has been focused on the physiological characters of theanine, exclusively in a clinical part because their role as antihypertensive agents and its capability to suppress stimulation by caffeine, to increase effects of antitumor agents. In plants theanine synthetase (EC 6.3.1.6) is used to synthesize theanine. Combination reaction of baker's yeast was used with bacterial glutaminases to produce theanine from glutamate and ethylamine also produce $\gamma$ glutamylmethylamide by using L-glutaminase from $P$. nitroreducens in addition to threonine by using methylamine as an acceptor of $\gamma$-glutamyl (Tachiki $\boldsymbol{e t}$ al., 1998). Scientists at the Taiyo Kagaku Co., Ltd., Japan, designed a technique for continuous manufacture of threonine using immobilized Pseudomonas nitroreducens as a source of L-glutaminase (Abelian $\boldsymbol{e t}$ al., 1993). Unfortunately, L-glutaminase and L-asparaginase can cause an allergic response leading to silent inactivation or inactivation of the drug. Currently, no therapeutically appropriate asparaginases and glutaminases presented which can be manufactured cheaply and with little or no contamination by other substances as endotoxins of a hos microorganism. Two probable mechanisms have been suggested for amidases especially L-asparaginase resistance (Woo et al., 2000). The first mechanism appears to be neutralization of L-asparaginases impeding their enzymatic activity by the production of anti-asparaginase antibodies in the host cells (Chakrabarti and Schuster, 1997). The second is related to an increase in asparagine synthase levels, which had been established in the blasts cells of patients with clinically unaffected to the drug (Asselin et al., 1999). For glutaminases, a suitable enzyme is unavailable in an amount large enough to permit for wide-spread clinical trials. For the amidases to be ideally matched for using in antineoplastic therapy, it should fulfill a diversity of criteria. The selected organisms should be able to grow in large quantities on an inexpensive and simple medium and give a high yield of amidases. The purification of the enzyme must be simplified as possible and rapid, handing ultrapure enzyme in high yield. The refined enzymes stability should have a long term on storage, a $\mathrm{Km}$ for substrate below it's in the blood and maximal activity at a physiological $\mathrm{pH}$. Besides, a full empathetic of the regulation of gene expression constructed on molecular methodologies and other factors would give great developing effective strategies for strain improvement which is critical for any industrially significant enzymes. Further researches and regulatory approvals will aid the introduction of new amidases drugs and other beneficial products with potential welfares (El-Ghonemy, 2014).

\section{CONCLUSION}

L-aparaginase and L-glutaminase from various sources have properties that act as an antineoplastic agent and also in another industrial process to minimize the risk of acrylamide and as flavor enhancing agent. Even though bacterial LAsparaginase and L-glutaminase are clinically applied for treatment of acute lymphoblastic leukemia and other types of cancer, it causes adverse reactions. For pharmaceutical applications and food industry, several studies to obtain LAsparaginase and L-glutaminase from novel sources to obtain extracted enzymes with prolonged half-life and higher specificity towards their substrate. Nowadays 
efforts going to the production of recombinant L-asparaginase and L-glutaminase by heterologous expression. Further studies on agro-industrial residues proved to be promising sources for the industrial production of these enzymes using SSF and controlling the factors during synthesis should improve the yield of the enzyme.

\section{REFERENCES}

Abdallah, N.A., Amer, S.K., Habeeb, M.K. 2012. Screening Of L-Glutaminase Produced By Actinomycetes Isolated From Different Soils In Egypt. International Journal of ChemTech Research, 4: 1451-1460.

Abd El-Baky, H., El Baroty, G. 2016. Optimization of Growth Conditions for Purification and Production of L-Asparaginase by Spirulina maxima. Evidence Based Complementary and Alternative Medicine, 7.Http://Dx.Doi.Org/10.1155/2016/1785938.

Abelian, H., Okubo, T., Mutoh, K., Chu, D., Kim, M., Yamamoto, T. 1993. A Continuous Production Method For Theanine By Immobilized Pseudomonas nitroreducens Cells. Journal Of Fermentation And Bioengineering, 76(3), 195 198.Https://Doi.Org/10.1016/0922-338X(93)90007-U

Abha, M. (2006).Production Of L-Asparaginase, Using Agricultural Waste In Solid State Fermentation. Applied Biochemistry And Biotechnology, 135:33-42. Https://Doi.Org/10.1385/ABAB:135:1:33.

Ahmad, N., Pandit, N., Maheshwari, S. 2012. L-Asparaginase Gene-A Therapeutic Approach Towards Drugs For A Cancer Cell. International Journal Of Biosciences, 2,1 -11. ISSN: 2220-6655 (Print) 2222-5234.

Ahmed, M., Taher, M., Nageh, F., Fareed, S. 2016. Process Optimization Of LGlutaminase Production; A Tumour Inhibitor From Marine Endophytic Isolate Aspergillus Sp. ALAA-2000 Journal Of Microbial, Biochemical Technology 9(8):256-267. Https://Doi.Org/10.4172/1948-5948.1000313.

Ali, E.M.M. 2009. Purification and characterization of Vigna unguiculata cultiva asparaginase. Journal of Biological Research-Thessaloniki, 11: 29-36. DOI: 10.4314/ejbmb.v27i1.43196.

Al Zobaidy, H. N., Kh, A., Shakir, G.M. 2016. Characterization Of LAsparaginase Purified From Pole Beans Strasburg. The Iraqi Journal Of Agricultural Science 47: 7, 129-137 ISSN: 0075053024100862.

Amena, S., Vishalakshi, N., Prabhakar, M., Dayanand, A.,Lingappa, K. 2010. Production, Purification And Characterization Of L-Asparaginase From Streptomyces gulbargensis. Brazilian Journal Of Microbiology, 41, 173-178. Https://Doi.Org/10.1590/S1517-838220100001000025.

Arima, K., Sakamoto, T., Araki, C., Tamura, G. 1972.Production Of Extracellular L-Asparaginases By Microorganisms. Agricultural And Biological Chemistry, 36: 356-361. Https://Doi.Org/10.1080/00021369.1972.10860270.

Asselin, B., Kreissman, S., Coppola, D., Bernal, S., Leavitt, P., Gelber, 1999. Prognostic Significance Of Early Response To A Single Dose Of Asparaginase In Childhood Acute Lymphoblastic Leukaemia. Journal Pediatric Hematology/Oncol, 21: 6-12.

Athira, R., Elizebeth, T., Narendra, T., Sheik, T., Gupta, S., Chaudary, M. Siddalingeshwara, K., And Pramod, T. 2014. Investigation On The Production Of L-Glutaminase From Pseudomonas stutzeri Strain Under Solid State Fermentation Using Various Agro Residues.Journal Of Drug Delivery, Therapeutics, 4(2), 81-85. Https://Doi.Org/10.22270/Jddt.V4i2.814.

Balagurunathan, R., Radhakrishnan, M., Somasundaram, S. 2010. L-Glutaminase Producing Actinomycetes From Marine Sediments-Selective Isolation, Semi Quantitative Assay And Characterization Of Potential Strain, Australian Journal Of Basic And Applied Sciences, 4(5): 698-705, 2010. ISSN 1991-8178.

Badoei-Dalfard, A. 2016. L-Asparaginase Production In The Pseudomonas pseudoalcaligenes Strain JHS-71 Isolated From Jooshan Hot-Spring. Molecular Biology Research Communications, 5(1), 1-10. PMCID:PMC5019328.

Bano M., Sivaramakrishnan V. M. 1980. Preparation And Properties Of LAsparaginase From Green Chillies (Capsicum annum L.). Journal Of Biosciences, 2(4), 291.Https://Doi.Org/10.1007/BF02716861.

Barbaree, M.J. Harless, E.J. 1995. Why bacteria are not enzymes and other essentials? National trade Publications, Atlanta.

Barnes, W.R., Vela, G.R. , Dorn, G.L. (1978). Physiology Of L-Asparaginase Synthesis In Recombinants Of Escherichia coli A1. Applied And Environmental Microbiology, 35:766-770. PMID: 25625.

Baskar, G, Renganathan, S. 2011. Optimization Of Media Components And Operating Conditions For Exogenous Production Of Fungal L-Asparaginase. Chiang Mai J Sci;38: 270-279.

Bhat, M., Marar T. 2015. Cytotoxic Effect Of Purified L-Asparaginase From Salinicoccus Sp. M KJ997975. International Journal Of Current Microbiology And Applied Sciences, 4(4): 701-712. ISSN: 2319-7706.

Binod, P., Sindhu, R., Madhavan, A., Abraham, A., Mathew, A. K., Beevi, U. S Sukumaran RK2, Singh SP Pandey, A.2017. Recent Developments In LGlutaminase Production And Applications-An Overview. Bioresource Technology, 245, 1766-1774. Https://Doi.Org/10.1016/J.Biortech.2017.05.059. Bon, E.P., Carvajal, E., Stanbrough, M., Rowen, D.,Magasanik, B. 1997.Asparaginase II Of Saccharomyces cerevisiae. GLN3/URE2 Regulation Of A Periplasmic Enzyme.Applied Biochemistry And Biotechnology, 63-65: 203-12.
Botman, D., Tigchelaar, W., Van, J.F. 2014. Determination Of PhosphateActivated Glutaminase Activity And Its Kinetics In Mouse Tissues Using Metabolic Mapping (Quantitative Enzyme Histochemistry). Journal Of Histochemistry Cytochemistry, $\quad$ 62(11): 826.Https://Doi.Org/10.1369/0022155414551177.

Brown, G., Singer, A., Proudfoot, M., Skarina, T., Kim, Y., Chang, C. Dementieva, I., Kuznetsova, E., Gonzalez, C.F., Joachimiak, A., Savchenko, A., Yakunin, A.F., 2008. Functional And Structural Characterization Of Four Glutaminases From Escherichia coli And Bacillus subtilis. Biochemistry 47 5724-5735. Https://Doi.Org/10.1021/bi800097h

Calderón, J., Huerta-Saquero, A., Du Pont, G., Durán, S., 1999. Sequence And Molecular Analysis Of The Rhizobium etli Glsa Gene, Encoding A Thermolabile Glutaminase. Biochimica et Biophysica Acta. 1444, 451-456. PMID:10095071.

Calimanti, A. 1922. Presence Of L-Asparaginase In Animals And Its Significance. Archives Internationales De Physiologie, 19:369398.Https://Doi.Org/10.3109/13813452209145156

Cedar, H., Schwartz, J. 1967. Localization Of The Two L-Asparaginases In Anaerobically Grown Escherichia coli. The Journal Of Biological Chemistry, 242:3753-3754. PMID: 4962587.

Chakrabarti, R., Schuster, S.M. 1997. L-Asparaginase: Perspectives On The Mechanisms Of Action And Resistance.International Journal Of Pediatric Hematology/Oncology, 4:597-611.

Cook, W., Hoffman, H., Bernlohr, W. 1981. Occurrence Of An Inducible Glutaminase In Bacillus licheniformis. Journal Of Bacteriology. 148: 365 367.1981. PMID: 7287627.

Costa, I. M., Schultz, L., De Araujo Bianchi Pedra, B., Leite, M. S., Farsky, S. H., De Oliveira, M. A., Pessoa, A., Monteiro, G. 2016. Recombinant LAsparaginase 1 From Saccharomyces cerevisiae: An Allosteric Enzyme With Antineoplastic Activity. Scientific Reports, 6, 36239. Doi:10.1038/Srep36239.

Curran, M.P., Daniel, R.M., Guy, G.R. , Morgan, H.1985. A Specific LAsparaginase From Thermus aquaticus. Archives Of Biochemistry And Biophysics, 241: 571-576.Https://Doi.Org/10.1016/0003-9861(85)90582-X.

Dejong, P.J. 1972. L-asparaginase production by Streptomyces griseus. Applied Microbioliology, 23: 1163-1164. PMCID: PMC380525.

Deshpande, N., Choubey, P., Agashe. M. 2014. Studies on Optimization of Growth Parameters for L-Asparaginase Production by Streptomyces ginsengisoli. The Scientific World Journal, 2014: 1-6. PMCID: PMC3925603.

Dhanam, J.G., Kannan, S. 2013. L-Asparaginase- Types, Perspectives And Applications. Advanced Biotechnology, 13: 1-5. ISSN 0973-0109.

Durgasi, K., Raju, K. 2016. Production And Optimization Of L-Glutaminase With Mixed Substrate Using Aspergillus wentii MTCC 1901 By Solid State Fermentation International Journal Of Engineering Research , Technology (IJERT) 5(6), ISSN: 2278-0181 Https://Www.Ijert.Org

Dutt, P.L.N.S.N., Siddalingeshwara, K.G., Karthic, J., Pramod, T., Vishwantha T., 2014. Antitumour Property L-Glutaminase On From Aspergillus oryzae Through Submerged Fermentation. International Journal of Current Microbiology and Applied Sciences. 3, 819-823.

Dutta, S. Roy, Rajanya, Lahiri, Dibyajit, 2015. L-Asparaginase And LGlutaminase From Pseudomonas aeruginosa: Production And Some Physicochemical Properties. Journal Of Microbiology, Biotechnology And Food Sciences. 05(01):34-39. Https://Doi.Org/10.15414/Jmbfs.2015.5.1.34-39.

Ebrahiminezhad, A., Rasoul-Amini, S., Ghoshoon, M.B.,Ghasemi, Y. 2014 Chlorella vulgaris, A Novel Microalgal Source For L-Asparaginase Production. Biocatalysis And Agricultural Biotechnology, $3 \quad$ (2), 214 217.Https://Doi.Org/10.1016/J.Bcab.2013.10.005.

El-Asmar, A., Greenberg, M. 1966. Studies On The Mechanism Of Inhibition Of Tumour Growth By The Enzyme Glutaminase. Cancer Research, 26: 116122.PMID: 5951788.

El-Bessoumy, A.A., Sarhan, M., Mansour, J. 2004. Production, Isolation, And Purification Of L-Asparaginase From Pseudomonas aeruginosa 50071 Using Solid-State Fermentation. Journal of Biochemistry And Molecular Biology,31;37(4):387-93.PMID:15469724

El-Gendy, M.M., Al-Zahrani, S.H., El-Bondkly, A.M., 2017. Construction Of Potent Recombinant Strain Through Inter-Generic Protoplast Fusion In Endophytic Fungi For Anticancerous Enzymes Production Using Rice Straw. Applied Biochemistry and Biotechnology. Http://Dx.Doi.Org/10.1007/S12010017-2429-0

EL-Ghonemy, D.H.E. 2014. Microbial Amidases And Their Industrial Applications: A Review. Journal Of Medical Microbiology And Diagnosis, 4:173.Https://Doi.Org/10.4172/21610703.1000173.

Elkomy, R.G. 2018. Optimization of 1-asparaginase produced by oscillatoria terebriformi isolated from Mediterranean Sea coast, Egypt. World Journal of Pharmaceutical Research, 7: 244-253.

Elkomy, R.G., Farag, A.M. 2018. Production Of Anti-Tumor L- Asparaginase By Free And Immobilized Marine Cyanobacterium Phormidium formosum As A Novel Source. International Journal Of Pharma And Bio Sciences. 9(4), 245 252. ISSN 0975-6299.

El-Naggar, N. E. 2015. Extracellular Production Of The Oncolytic Enzyme, LAsparaginase, By Newly Isolated Streptomyces Sp. Strain NEAE95 As Potentia Microbial Cell Factories: Optimization Of Culture Conditions Using Response 
Surface Methodology. Current Pharmaceutical Biotechnology.16, 162-178. PMID: 25395212.

El-Sayed, A. 2009. L-Glutaminase Production By Trichoderma koningii Under Solid State Fermentation. Indian Journal Of Microbiology, 49: 243 250.Https://Doi.Org/10.1007/S12088-009-0020-2.

Elshafei, A.M, Hassan, M., Abouzeid, M.A., Mahmoud, D.A., Elghonemy, D.H 2012. Purification, Characterization And Antitumor Activity Of L-Asparaginase From Penicillium brevicompactum NRC 829. British Microbiology Research Journal, 2(3): 158-174.Https://Doi.Org/10.9734/BMRJ/2012/1735.

Elshafei, A.M., Hassan, M., Abouzeid, M., Mahmoud, D., El-Ghonemy D. 2014. Purification, Kinetic Properties And Antitumoractivity Of L-Glutaminase From Penicillium brevicompactum NRC 829. British Microbiology Research Journal, 4: 93-111.Https://Doi.Org/10.9734/BMRJ/2014/5098.

Elzainy, Tahany A., Thanaa, H. A.2006. "Detection Of The Antitumor Glutaminase-Asparaginase In The Filamentous Fungi." Journal of Applied Sciences. 6.1: 1389-1395. 10.3923/jas.2006.1389.1395.

Erva, R., Venkateswarulu, T., Bangaraiah, P. 2018. Multi-Level Statistical Optimization Of L-Asparaginase From Bacillus subtilis. Journal Of Biotechnology, 8:24.Https://Doi.Org/10.1007/S13205-017-1020-2.

Farag, A.M., Hassan, S.W., Beltagy, E.A., El-Shenawy, M.A. 2015. Optimization Of Production Of Anti-Tumor L-Asparaginase By Free And Immobilized Marine Aspergillus terreus. Egyptian Journal Of Aquatic Research, 41 (4), 295302.Https://Doi.Org/10.1016/J.Ejar.2015.10.002.

Faret, M., De Morais, S.B., Zanchin, N.I.T. 2018. L-Asparaginase From Erwinia carotovora: Insights About Its Stability And Activity. Molecular Biology Reports. Https://Doi.Org/10.1007/S11033-018-4459-2.

Fisher, S.H., Wray, L.V., 2002. Bacillus Subtilis 168 Contains Two Differentially Regulated Genes Encoding L -Asparaginase. Journal of Bacteriolology. 184 2148-2154. Https://Doi.Org/10.1128/JB.184.8.2148.

Foda, M.S., Zedan, H.H. , Hashem, S.A. 1980. Formation And Properties Of LGlutaminase And L-Asparaginase Activities In Pichia polymorpha. Acto Microbiologica Polonica, 29: 343-352. PMID: 6164254.

Gaffar, S., Shethna, Y. 1977. Purification And Some Biological Properties Of Asparaginase From Azotobacter vinelandii. Applied And Environmental Microbiology, 33:508-514.PMCID: PMC170717.

Geckil, H., Gencer, S. 2004. Production Of L-Asparaginase In Enterobacter aerogenes Expressing Vitreoscilla Hemoglobin For Efficient Oxygen Uptake. Applied And Environmental Microbiology, 63:691-697. Https://Doi.Org/10.1007/S00253-003-1482-5.

Greenberg, D., Blumenthal, G., Ramadan, M. 1964. Effect Of Administration Of The Enzyme Glutaminase On The Growth Of Cancer Cells. Cancer Research, 24 957-963.PMID: 14195348.

Gulati, R., Saxena, R., Gupta, R. 1997. A Rapid Plate Assay For Screening L Asparaginase Producing Micro-Organisms. Letters Applied Microbiology, 24 23-26. PMID: 9024001.

Gunasekaran, S., Mc Donald, L., Manavathu, M., Manavathu, E, Gunasekaran, M. 1995. Effect of culture media on growth and L-asparaginase production in Nocardia asteroids. Biomedical Letters, 52: 197.

Hamada, J.S., Marshall, W.E. 1988. Enhancement Of Peptidoglutaminase Deamidation Of Soy Protein By Heat Treatment And/Or Proteolysis. Food Science. 53:1132-1134. Https://Doi.Org/10.1111/J.1365-2621.1988.Tb13546.X. Hashizume, R., Maki, Y., Mizutani, K., Takahashi, N.,Matsubara, H., Sugita, A. Sato, K., Yamaguchi, S., Mikami, B. 2011. Crystal Structures Of Protein Glutaminase And Its Pro Forms Converted Into Enzyme-Substrate Complex. Journal Of Biological Chemistry, 286: 38691-38702. Https://Doi.Org/10.1074/Jbc.M111.255133.

Hatanaka, T., Usuki, H., Arima, J., Uesugi, Y., Yamamoto, Y., Kumagai, Y. Yamasato, A., Mukaihara, T., 2011. Extracellular Production And Characterization Of Two Streptomyces L-Asparaginases. Applied Biochemistry and Biotechnology. 163, 836-844. Https://Doi. Org/10.1007/S12010-010-9087-9. Heinemann, B., Howard, A.J. 1969. Production Of Tumor-Inhibitory LAsparaginase By Submerged Growth Of Serratia marcescens.Applied Microbiolology. 18(4):550-4. PMCID: PMC378033.

Abd-Alla, M.H., El-Sayed, E.A., Rasmey, A.M. 2013. Biosynthesis of L Glutaminase by Streptomyces Variabilis ASU319 Isolated from Rhizosphere of Triticum Vulgaris. Universal Journal of Microbiology Research, 1(3): 27-35. DOI: 10.13189/ujmr.2013.010301.

Hendriksen, H.A.V.H., Ornbrust, B.E.A.K., Stergaard, P.E.R.., 2009. Evaluating the potential for enzymatic acrylamide mitigation in a range of food products using an asparaginase from Aspergillus oryzae. Journal of Agricultural and Food Chemistry. 4168-4176. http://dx.doi.org/10.1021/ jf900174q

Hong, S.J., Lee, Y.H., Khan, A.R., Ullah, I., Lee, C., Park, C.K., Shin, J.H., 2014. Cloning, Expression, And Characterization Of Thermophilic LAsparaginase From Thermococcus kodakarensis KOD1. Journal of Basic Microbiology. 54, 500-508. Https://Doi.Org/10.1002/Jobm.201300741

Hosamani, R, Kaliwal, B.B. 2011. L-Asparaginase-An Antitumor Agen Production By Fusarium equiseti Using Solid State Fermentation. International $\begin{array}{llll}\text { Journal Of Drug Discovery, } & \text { 3:88-99. }\end{array}$ Http://Www.Bioinfo.In/Contents.Php?Id=24
Huang, Y.L., Khoo, S.B., Yap, M.G. 2006. Determination Of Glutamine In Mammalian-Cell Culrures With A Flow-Injection Analysis Wall-Jet Electrode System. Analytical Letters, $28 \quad 28$ (4):593 603.Https://Doi.Org/10.1080/00032719508001120.

Huerta-Saquero, A., Calderon, J., Arreguin, R., Calderon-Flores, A., Duran, A 2001. Overexpression And Purification Of Rhizobium etli Glutaminase A By Recombinant And Conventiona Procedures. Protein Expression and Purification. 38, 272-278. Https://Doi.Org/10.1006/prep.2001.1394.

Husain, I., Sharma, A., Kumar, S., Malik, F. 2016. Purification And Characterization Of Glutaminase Free Asparaginase From Pseudomonas otitidis Induce Apoptosis In Human Leukemia MOLT-4 Cells. Biochimie. 121:38-51 Https://Doi.Org/10.1016/J.Biochi.2015.11.012.

Imada, A., Igarasi, S., Nakahama, K., Isona, M. 1973.Asparaginase And Glutaminase Activities Of Microorganisms. Journal Of General And Applied Microbiology, 76: 85-99. Https://Doi.Org/10.1099/00221287-76-1-85.

Inada, Y., Furukawa, M., Sasaki, H., Kodera, Y., Hiroto, M. 1995, Biomedical And Biotechnological Applications Of PEG- And PM-Modified Proteins. Biotechnology, 13: 86-91. Https://Doi.Org/10.1016/S0167-7799(00)88912-X.

Ito, K., Matsushima, K., Koyamab, Y., 2012. Gene Cloning, Purification, And Characterization Of A Novel Peptidoglutaminase-Asparaginase From Aspergillus sojae. Applied and Environmental Microbiology. 78, 5182-5188 Https://Doi.Org/10.1128/AEM.00765-12

Ito, K., Hanya, Y., Koyama, Y. 2013.Purification And Characterization Of A Glutaminase Enzyme Accounting For The Majority Of Glutaminase Activity In Aspergillus sojae Under Solid-State Culture. Applied Microbiology And Biotechnology. 97(19):8581-90. Https://Doi.Org/10.1007/S00253-013-4693-4.

Ito, K., Umitsuki, G., Oguma, T., Koyama, Y., 2011. Salt-Tolerant And Thermostable Glutaminases Of Cryptococcus Species Form A New Glutaminase Family. Bioscience, Biotechnology, and Biochemistry. 75 (7), 1317-1324. Https://Doi.Org/10.1271/bbb.110092.

Iyer, P., Singhal, R. 2009. Screening And Selection Of Marine Isolate For LGlutaminase Production And Media Optimization Using Response Surface Methodology. Applied Biochemistry And Biotechnology, 159: 233-250. Https://Doi.Org/10.1007/S12010-008-8522-7.

Iyer,P., Singhal, R. 2010. Glutaminase Production Using Zygosaccharomyces rouxii NRRL-Y 2547: Effect Of Aeration, Agitation Regimes And Feeding Strategies. Chemical Engineering, Technology, 33: 52-62. Https://Doi.Org/10.1002/Ceat.200900230.

Jia, M., Xu, M., He B., Rao, Z. (2013). Cloning, Expression And Characterization Of L-Asparaginase From A Newly Isolated Bacillus subtilis B11-06. Journal Of Agricultural And Food Chemistry, 61:9428-9434 DOI: $10.1021 / \mathrm{jf} 402636 \mathrm{w}$.

Kang, M.H., Kang, Y.H., Szymanska, B., Wilczynska-Kalak, U., Sheard, M.A, Harned, T.M.,Lock, R.B., Reynolds, 2007. Activity Of Vincristine, L-ASP, And Dexamethasone Against Acute Lymphoblastic Leukemia Is Enhanced By The BH3-Mimetic ABT-737 In Vitro And In Vivo. Blood. 110(6):2057-66 Https://Doi.Org/10.1182/Blood-2007-03-080325.

Kashyap, P. Sabu, A, Pandey A, Szakacs, G, Carlos, R.2002.Extra-Cellular LGlutaminase Production By Zygosaccharomyces rouxii Under Solid-State Fermentation. Process Biochemistry .38:307-31. Https://Doi.Org/10.1016/S0032 9592(02)00060-2.

Keerthi, T., Suresh, P., Sabu, A., Rajeevkumar, S., Chandrasekaran, M. 1999. Extracellular Production Of Lglutaminase By Alkalophilic Beauveria bassiana BTMF S10 Isolated From Marine Sediments. World Journal Of Microbiology, Biotechnology, 15:751-752.Https://Doi.Org/10.1023/A:1008902111799.

Kelo, E., Noronkoski, T., Mononen, I. 2009. Depletion Of L-Asparagine Supply And Apoptosis Of Leukemia Cells Induced By Human Glycosylasparaginase. Leukemia, 23 (6), 1167-1171.Https://Doi.Org/10.1038/Leu.2008.387.

Kidd, J. G. 1953. Regression Of Transplanted Lymphomas Induced In Vivo By Means Of Normal Guinea Pig Serum. I. Course Of Transplanted Cancers Of Various Kinds In Mice And Rats Given Guinea Pig Serum, Horse Serum, Or Rabbit Serum. Journal Of Experimental Medicine, 98:565-606.PMCID: PMC2136344.

Kikuchi, M., Sakaguchi, K. 1973. Some Enzymatic Properties And Substrate Specificities Of Peptidoglutaminase-I And II. Agricultural And Biological Chemistry, 37:1813-1821. https://doi.org/10.1271/bbb1961.37.1813.

Kiran, K., Chandran R., Aswathi C. 2011. Extraction And Purification Of LAsparaginase, L-Glutaminase From Capsicum annuum Varieties And Their Molecular Characterization. International Journal Of Agriculture Environment And Biotechnology, 4 :4, 363-370.ISSN : 0974-1712.

Krishnakumar,S., Rajan, R., Ravikumar, S. 2011. Extracellular Production Of L Glutaminase By Marine Alkalophilic Streptomyces Sp.-SBU1 Isolated From Cape Comorin Coast. Indian Journal Of Geo-Marine Sciences, 40(5). http://nopr.niscair.res.in/handle/123456789/13084.

Kiruthika, J., Nachimuthu, S. 2013. Production Of L-Glutaminase And Its Optimization From A Novel Marine Isolate Vibrio azureus JK-79 African Journa Of Biotechnology, 2 (50), 6944-6953, https://Doi.Org/10.5897/AJB2013.13107.

Koibuchi, K., Nagasaki, H., Yuasa, A., Kataoka, J., Kitamoto. K. 2000 Molecular Cloning And Characterization Of A Gene Encoding Glutaminase 
From Aspergillus oryzae. Applied Microbiology Biotechnology, 54: 59-68. https://Doi.Org/10.1007/S002530000329.

Kotzia, G., Lappa, K., Labrou, N. 2007. Tailoring Structure-Function Properties Of L-Asparaginase: Engineering Resistance To Trypsin Cleavage (337-43) Biochemical Journal. 404. https://Doi.Org/10.1042/BJ20061708.

Kumar, K.P.V., Girija, S.G., Prabhakar, T. 2011. Optimization of L-asparginase production by Streptomyces griseoluteus WS3/1 using experimental methods. Journal of Pharmaceutical and Biomedical Sciences, 10: 1-6.

Kumar, K., Kataria, M., Verma, N. 2013. Plant Asparaginase-Based Asparagine Biosensor For Leukemia. Artificial Cells, Nanomedicine, And Biotechnology, 41 184 -188. Https://Doi.Org/10.3109/10731199.2012.716062.

Kumar, S.R., Chandrasekaran, M. 2003. Continuous Production Of LGlutaminase By An Immobilized Marine Pseudomonas Sp. BTMS-51 In A Packed Bed Reactor. Process Biochemistry, 38: 14311436.Https://Doi.Org/10.1016/S0032-9592(03)00035-9.

Kumar, S., Sobha, K. 2012. L-Asparaginase From Microbes: A Comprehensive Reviewarticle. Advances In Bioresearch, 3(4):137-157.

Lakshmanaperumalsamy, P. 2009. Solid State Fermentation For Production O L-Asparaginase In Rice Bran By Serratia marcescens SB08. The Internet Journal Of Microbiology,7 (1)10-18.

Lea, P.J., Festenstein, G.N., Hughes, J.S., Miflin, B.J. 1984. An immunological and enzymological survey of asparaginase in seeds of Lupinus. Phytochemistry, 23: 511-514. https://doi.org/10.1016/S0031-9422(00)80369-6.

Lindsay R.C., Jang S. 2005. Model Systems For Evaluating Factors Affecting Acrylamide Formation In Deep Fried Foods. In: Friedman M., Mottram D. (Eds) Chemistry And Safety Of Acrylamide In Food. Advances In Experimenta Medicine And Biology, Springer, Boston, MA, 561.ISBN 978-0-387-24980-3 Https://Doi.Org/10.1007/0-387-24980-X 25.

Liu, C., Lijuan, L., Qinlu, L. 2019. Antitumor Activity And Ability To Prevent Acrylamide Formation In Fried Foods Of Asparaginase From Soybean Roo Nodules. Journal of Food And Biotechmistery. https://doi.org/10.1111/jfbc.12756.

Liu, F., Zajic, J. 1973. Fermentation Kinetics And Continuous Process Of LAsparaginase Production. Applied Microbiology, 25:92-96. PMCID PMC380741.

Lobo, C., Ruiz-Bellido, M.A., Aledo, J.C., Márquez, J., Núñez, I., Alonso, F.J. 2000. Inhibition Of Glutaminase Expression By Antisense Mrna Decreases Growth And Tumourigenicity Of Tumour Cells. Biochemical Journal, 348, $257-$ 261. Https://Doi.Org/10.1042/0264-6021:3480257.

Mahajan, R. V., Saran, S., Kameswaran, K., Kumar, V., Saxena, R. K. 2012. Efficient Production Of L-Asparaginase From Bacillus licheniformis With Low glutaminse Activity: Optimization, Scale Up And Acrylamide Degradation Studies. Bioresource Technology. 125,11-16. Https://Doi.Org/10.1016/j.biortech.2012.08.086.

Maria, A., Neuza, M., Jos'E, J., Adriana, S., Edna, M., Antonio, C. 2006. Asparaginase Production By A Recombinant Pichia Pastoris Strain Harbouring Saccharomyces cerevisiae ASP3 Gene. Enzyme And Microbial Technology, 39:1457-1463.Https://Doi.Org/10.1016/J.Enzmictec.2006.03.036.

Masuo, N., Ito, K., Yoshimune, K., Hoshino, M., Matsushima, K., Koyama, Y. Moriguchi, M., 2004. Molecular Cloning, Overexpression, And Purification Of Micrococcus luteus K-3-Type Glutaminase From Aspergillus oryzae RIB40.

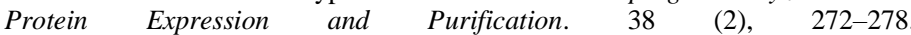
Https://Doi.Org/10.1016/j.pep.2004.09.003.

Meyerhoff, M., Duan, C., Meusel, M. 1995. Novel Non Separation SandwichType Electrochemical Enzyme Immunoassay System For Detecting Marker Proteins In Undiluted Blood. Clinical Chemistry, 41(9),1378-1384. PMID: 7544708 .

Miki, A., Koichi, S., Toshiyuki, K., Mahato, S., Kouichi, M., Jun, A. 2005 Selective Apoptosis Of Natural Killer-Cell Tumors By L-Asparaginase. British Journal Of Haematology, 130: 860-868. Https://Doi.Org/10.1111/J.13652141.2005.05694.X

Miller, H.K., Salser, J.S., Balis, M.E. 1969. Amino Acid Levels Following LAsparagine Amidohydrolase (EC. 3.5.1.1) Therapy. Cancer Research, 29:183187. PMID: 5763976

Moharib, S. 2018.Anticancer Activity Of L-Asparaginase Produced From Vigna $\begin{array}{llll}\text { Unguiculata. World Scientific Research, } & \text { 5(1): }\end{array}$ Https://Doi.Org/10.20448/journal.510.2018.51.1.12.

Mohamed, S.A., Elshal, M.F., Kumosani, T.A., Aldahlawi, A.M. 2015 Purification and Characterization of Asparaginase from Phaseolus vulgaris Seeds Evidence-Based Complementary and Alternative Medicine, 2015: 1-6. http://dx.doi.org/10.1155/2015/309214.

Mohapatra, B.R., Sani, R.K., Banerjee, U.C. 1995.Characterization Of LAsparaginase From Bacillus sp. Isolated From An Intertidal Marine Alga (Sargassum Sp.).Letters In Applied Microbiology, 21:380-383 Https://Doi.Org/10.1111/J.1472-765X.1995.Tb01086.X.

Morales, F., Capuano, E., Fogliano, V. 2008. Mitigation Strategies To Reduce Acrylamide Formation In Fried Potato Products. Annals Of The New York Academy Of Sciences, 1126, 89 -100. Https://Doi.Org/10.1196/Annals.1433.051. Moriguchi, M., Sakai, K., Tateyama, R., Furuta, Y., Wakayama, M 1994.Isolation And Characterization Of Salt Tolerant Glutaminases From Marine
Micrococcus luteus K3.Journal Of Fermentation And Bioengineering, 77, 621 625. Https://Doi.Org/10.1016/0922-338X(94)90143-0.

Mostafa, S.A. 1979. Production of L-asparaginase by Streptomyces karnatakensis and Streptomyces venezuelae. Zentralbl Bakteriology, 134: 429-436. PMID: 44413.

Mottram, D.S., Wedzicha, B.L., Dodson, A.T. 2002. Food Chemistry: Acrylamide Is Formed In The Maillard Reaction.Nature, 419, $448-449$. Https://Doi.Org/10.1038/419448a.

Mukherjee, J., Majumdar, S., Scheper, T. 2000. Studies On Nutritional And Oxygen Requirements For Production Of L-Asparaginase By Enterobacter aerogenes. Applied Microbiology And Biotechnology, 53:180-184 Https://Doi.Org/10.1007/S002530050006.

Nageswara, S., Kamalakumari, P.V, Girija, S. Prabhakar, T. 2014. Production Of L-Asparaginase By Solid State Fermentation Using Marine Fungus.Biomed Research International,1(1)1-9. www.Bmrjournals.Comid: BC14 01.

Nagwa, A., Shaimaa, K., Mario, K. 2012.Screening Of L-Glutaminase Produced By Actinomycetes Isolated From Different Soils In Egypt. International Journal Of Chemtech Research,4(4),1451-1460. ISSN : 0974-4290

Nanda, K.R., Yoshimune, K., Wakayama, M., \& Moriguchi, M. (2003) Microbial Glutaminase: Biochemistry, Molecular Approaches And Application In The Food Industry. Journal Of Molecular Catalysis B: Enzymatic, 23:87-100 Https://Doi.Org/10.1016/S1381-1177(03)00075-4.

Narayana, K.J., Kumar, K.G., Vijayalakshmi, M. (2008). L-Asparaginase Production By Streptomyces albidoflavus. Indian Journal Of Microbiology, 48 331-336. Https://Doi.Org/10.1007/S12088-008-0018-1.

Nathiya, K., Soraj, S.S., Angayarkanni, J., Palaniswamy, M. 2011. Optimised Production Of L- Glutaminase: A Tumor Inhibitor From Aspergillus flavus Cultured On Agro Industrial Residues. Afr J Biotechnol.;10:13887-94 Https://Doi.Org/10.5897/AJB11.1251.

Oliveira, E., Martins, A., Carvajal, E., Bon, E. 2003. The Role Of The GATA Factors Gln3p, DAL80 And The Ure2p On Asp3 Regulation In Saccharomyces cerevisae. Yeast, 20:31-37. Https://Doi.Org/10.1002/Yea.930.

Oza V.P., S.D. Trivedi, P.P. Parmar , R.B. Subramanian 2009. Withania somnifera L. (Ashwagandha): A Novel Source Of L-Asparaginase. Journal Of Integrative Plant Biology,51(2),201. Https://Doi.Org/10.1111/J.1744 7909.2008.00779.X

Pallem, C., Manipati, S., Somalanka,S.R. 2010. Process Optimization Of LGlutaminase Production By Trichoderma koningii Under Solid State Fermentation (SSF). International Journal Of Applied Biology And Pharmaceutical Technology, 1:1168-1174.ISSN 0976-4550.

Paul, J.H. 1982. Isolation and characterization of a Chlamydomonas Lasparaginase. Biochemistry Journal, 203(1):109-115. PMCID: PMC1158199.

Pedreschi, F., Kaack, K., Granby, K. 2008. The Effect Of Asparaginase On Acrylamide Formation In French Fries. Food Chemistry Journal, 109: 386-392. Https://Doi.Org/10.1016/J.Foodchem.2007.12.057.

Peter, J. 1972. L-Asparaginase Production By Streptomyces griseus. Applied Microbiology, 23:1163-1164. PMCID: PMC380525.

Peterson, R., Ciegler, A. 1969. L-Asparaginase Production By Erwinia aroideae. Journal Of Applied Microbiology, 18:64-67.PMID: 5803630.

Peterson, R., Ciegler, A. 1972. Factors Influencing L-Asparaginase Production By Erwinia aroideae. Journal Of Applied Microbiology, 23: 671-673. PMCID PMC380410.

Prabhu, G.N., Chandrasekaran, M. 1997. Impact Of Process Parameters On LGlutaminase Production By Marine Vibrio costicola Under Solid State Fermentation Using Polystyrene As Inert Support. Process Biochemistry.; 32: 285-289. ISSN 1359-5113. https://doi.org/10.1016/S0032-9592(96)00083-0.

Prihanto, A., Wakayama, M. 2016. Marine Microorganism: An Underexplored Source Of L-Asparaginase. Advances In Food And Nutrition Research,79:1-25. Https://Doi.Org/10.1016/Bs.Afnr.2016.07.005

Prista, A.A., Kyridio, D.A. 2001. L-Asparaginase Of Thermus thermophilus Purification, Properties And Identification Of Essential Amino Acids For Catalytic Activity. Molecular And Cellular Biochemistry, 216:93-101. PMID: 11216870

Radha, R., Arumugam, N., Gummadi, S.N., 2018. Glutaminase Free LAsparaginase From Vibrio cholerae: Heterologous Expression, Purification And Biochemical Characterization. International Journal of Biological Macromolecules. 111, 129-138. Https://Doi.Org/10.1016/J.Ijbiomac.2017.12.165 Revanth, B., Raju, K., 2013. L-Glutaminase Production By Aspergillus wenti MTCC 1901 Under Solid State Fermentation Using Mixed Agro Industria Residues, International Journal Of Chemical Sciences, 11(1):277-290.

Roberts, J. 1976. Purification And Properties Of Highly Potent Anti-Tumour Glutaminase Asparaginase From Pseudomonas 7A.The Journal Of Biological Chemistry, 247:84-90. PMID: 5441.

Roberts, J., Holcenberg, J.S., Dolowy, W.C. 1970. Antineoplastic Activity Of Highly Purified Bacterial Glutaminase. Nature, 227:1136-7. Https://Doi.Org/10.1038/2271136a0

Roberts, J., Holcenberg, J.S., Dolowy, W.C. 1972.Isolation, Crystallization And Properties Of Achromobacteraceae Glutaminase- Asparaginase With Antitumor Activity. The Journal Of Biological Chemistry, 247, 84-90. PMID:5017769. 
Sabu, A., Keerthi, T.R., Rajeev, K.S., Chandrasekaran, M. 2000. L-Glutaminase Production By Marine Beauveria sp. Under Solid State Fermentation. Process Biochemistry, 35: 705-710. https://doi.org/10.1016/S0032-9592(99)00127-2. Sajitha, S., Vidya, J., Varsha, K., Binod, P., Pandey, A. 2015. Cloning And Expression Of L-Asparaginase From E. coli In Eukaryotic Expression System. Biochemical Engineering Journal, 102, 14-17. Https://Doi.Org/10.1016/J.Bej.2015.02.027.

Saleem, N.B., Rekha, R., Komala, M., Ruby, S. 2009.Production Of Extracellular Anti-Leukaemic Enzyme L-Asparaginase From Marine Actinomycetes By Solid State And Submerged Fermentation: Purification And Characterisation. Tropical Journal Of Pharmaceutical Research, 8:353-360. Http://Dx.Doi.Org/10.4314/Tjpr.V8i4.45230.

Sanjay, K., Pakshirajan, K., Venkata, D.V. 2009. Development Of Medium For Enhanced Production Of Glutaminase-Free L-Asparaginase From Pectobacterium carotovorum MTCC1428. Applied Microbiology And Biotechnology, 84:477-486. Https://Doi.Org/10.1007/S00253-009-1973-0.

Sanjotha, G., Sudheer, I. 2017. Isolation, Screening, Optimization And Production Of Anti-Tumer Asparaginase By Fungi From Karwar Coastal Region. Research Journal Of Recent Sciences Vol. 6(3), 1-7. ISSN 2277-2502.

Sarada, K.V., 2013. Production And Applications Of L-Glutaminase Using Fermentation Technology. Asia-Pacific Journal of Research. 1, 1-4.

Saravanan, D., Bharathi, S., Radhakrishnan, M., Balagurunathan, R. 2014 Production And Optimization Of L-Glutaminase From Vibrio sp. M9 Isolated From Mahabalipuram Marine Sediments. World Journal Of Pharmaceutical Research. 3(2), 2117.

Sarquis, M., Oliveira, E., Santos, A., Costa, G. 2004.Production Of LAsparaginase By Filamentous Fungi. The Memórias Do Instituto Oswaldo Cruz, 99:489-492. Https://Doi.Org/S0074-02762004000500005.

Sato, I., Kobayashi, H., Hanya, Y., Abe, K., Murakami, S., Scorzetti, G. 1999.Cryptococcus Nodaensis Sp Nov, A Yeast Isolated From Soil In Japan That Produces A Salt Tolerant And Thermostable Glutaminase. Journal Of Industria Microbiology And Biotechnology, 22,127-132. Https://Doi.Org/10.1038/Sj.Jim.2900623.

Saxena, A., Upadhyay, R., Kango, N. 2015. Isolation and identification of actinomycetes for production of novel extracellular glutaminase free Lasparaginase. Indian Journal of Experimental Biology, 53: 786-793. PMID: 26742323.

Shakambari, G., Ashokkumar, B., Varalakshmi, P. 2019. L-Asparaginase-A Promising Biocatalyst For Industrial And Clinical Applications. Biocatalysis And Agricultural Biotechnology. 17, 213-224. Https://Doi.Org/10.1016/J.Bcab.2018.11.018

Shanmugaprakash, M., Jayashree, S., Siddiqui, S. R. Arshad 2015.Biochemical Characterization And Antitumor Activity Of Three Phase Partitioned LAsparaginase From Capsicum annuum L. Separation And Purification Technology, 142: 258-267. https://doi.org/10.1016/j.seppur.2014.12.036.

Sieciechowicz, K.A., Ireland, R.J. 1989. Isolation and properties of an asparaginase from leaves of Pisum sativum. Phytochemistry, 28: 2275-2279. DOI: 10.1016/S0031-9422(00)97967-6.

Sindhwad, P., Desai, K. 2015. Media Optimization, Isolation And Purification Of L-Asparaginase From Marine Isolate. Asian Pacific Journal Of Health Sciences. 2(3):72-82. E-ISSN: 2349-0659, P-ISSN: $2350-0964$ DOI: $10.21276 /$ apjhs.2015.2.3.16.

Sinha R., Singh H. R., Jha S. K. (2013). L-Asparaginase:Present And Future Prospective. The International Journal Of Innovative Research In Science, Engineering And Technology, 2, 7031-7051. ISSN: 2319-8753.

Sinha, S., Nigam, V. 2016. Production And Characterization Of L-Glutaminase By Bacillus sp. International Journal Of Pharmaceutical Sciences And Research, 7(4): 1620-1626. Https://Doi.Org/10.13040/IJPSR.0975-8232.

Sinsuwan, S., Yongsawatdigu, J., Chumseng, S., Yamabhai, M., 2012. Efficient Expression And Purification Of Recombinant Glutaminase From Bacillus licheniformis (Glsa) In Escherichia coli. Protein Expression Purification. 83, 52 58. Https://Doi.Org/10.1016/j.pep.2012.03.001

Soda, K., Ohshima, M., Yamamoto, T. 1972. Purification And Properties Of Isoenzymes Of Glutaminase From Pseudomonas aeroginosa. Biochemical And Biophysical Research Communications Journal, 46,1278-1284. PMID: 4622222.

Soniyamby, A.R., Lalitha, S., Praveesh, B.V., Priyadarshini, V. 2011. Isolation, Production And Anti-Tumor Activity Of L-Asparaginase Of Penicillium sp. International Journal Of Microbiological Research, 2(1), 38.

Spiers, A.S., Wade, H.E. 1976. Bacterial Glutaminase In Treatment Of Acute Leukaemia. British Medical Journal,1:1317-1319. PMID: 773514.

Sudarkodi, C., Sundar S. K. 2018. Anticancer Activity Of L-Asparaginase From Aspergillus oryzae Against Hep G2 And Hela Cell Lines. International Journal Of Recent Scientific Research. 9(3), 25328-25330.

Sunil D.P., Siddalingeshwara, K.G., Karthic, J.,Pramod, T.,Vishwanath, T. 2014 Antitumour Property L-Glutaminase From Aspergillus oryzae Through Submergrd Fermentation. International Journal Of Current Microbiology And Applied Sciences, 3(3): 819-823 ISSN: 2319-7706.

Suresh, S., Muthuvelayudham, R., Viruthagiri, T. 2013. Production And Optimization Of L-Glutaminase (EC.3.5.1.2) By Serratia marcescens Using Wheat Bran Under Statistical Designs. Journal Of Chemical, Biological And
Physical Sciences, 3(4), 2601-2612. Available Online At:www.Isca.In, Www.Isca.Me.

Swain, A.L., Jaskolski, M., Housset, D., Rao, J.K., Wlodawer A. 1993. Crystal Structure Of Escherichia coli L-Asparaginase, An Enzyme Used In Cance Therapy.Proceedings Of The National Academy Of Sciences USA, 90: 14741478. PMCID:PMC45896.

Tachiki, T., Yamada, T., Mizuno, K., Ueda, M., Shiode, J., Fukami, H. 1998.ГGlutamyl Transfer Reactions By Glutaminase From Pseudomonas nitroreducens IFO 12694 And Their Application For The Syntheses Of Theanine And $\Gamma$ Glutamyl Methylamide. Bioscience, Biotechnology, And Biochemistry, 62:127983. Https://Doi.Org/10.1271/Bbb.62.1279.

Thanaa, H.A., Nadia, H.A., Latifa, A. 2009. Glutamine Amidohydrolase From Penicillium politans NRC 510. Polish Journal Of Food And Nutrition Sciences, 59(3),211-217. Http://Journal.Pan.Olsztyn.Pl.

Thenmozhi, C., Sankar, R., Karuppiah, V., Sampathkumar, P. 2011. LAsparaginase Production By Mangrove Derived Bacillus Cereus MAB5: Optimization By Response Surface Methodology. Asian Pacific Journal Of Tropical Medicine. 4:486-491. Https://Doi.Org/10.1016/S1995-7645(11)60132$\underline{6}$.

Tork, S., Magda, M., Elsemin, O. 2018. A New L-Glutaminase From Streptomyces pratensis NRC 10: Gene Identification, Enzyme Purification, And Characterization. International Journal Of Biological Macromolecules, 113: 550-557. Https://Doi.Org/10.1016/J.Ijbiomac.2018.02.080.

Unissa, R., M. S., Reddy, A., Naga, S. 2014. A Review On Biochemical And Therapeutic Aspects Of Glutaminase. International Journal Of Pharmaceutical Sciences And Research, 5(11): 4617-4634. DOI: http://dx.doi.org/10.13040/IJPSR.0975-8232.5(11).4617-34.

Varma, A, Sushma, K., Naga, V., Bodaiah,Sudhakar P. 2016. Partial Purification, Characterization And Optimization Of Anti-Leukemic Enzyme L-Asparaginase From Mangrove Soil Actinobacteria. Journal Of Pharmacy Research 2016,10(7),502-511 .ISSN: 0974-6943 Http://Jprsolutions.Info.

Verma, N., Bansa, M., Kumar, S. 2012. Whole Cell Based Miniaturized Fiber Optic Biosensor To Monitor L-Asparagine. Journal Of Applied Sciences Research; 3, 809-814.

Venil C., Nanthakumar K., Karthikeyan K., Perumalsamy L. 2009. Production Of L-Asparaginase By Serratia marcescens SB08: Optimization By Response Surface Methodology. Iranian Journal Of Biotechnology, 7(1).

Vidhya, M., Aishwarya, R., Alagarsamy, S., Rajesh, T.S. 2010. Production, Purification And Characterisation Of Extracellular L-Asparaginase From A Soil Isolate Of Bacillus sp African Journal Of Microbiology Research, 4: 18621867. Available Online Http://Www.Academicjournals.Org/Ajmr.

Vidya, J., Vasudevan, U. 2011. Cloning, Functional Expression And Characterization Of Lasparaginase II From E. coli MTCC 739. Food Technology. 9862, 286-291.

Wakayama, M., Yamagata, T., Kamemura, A., Bootim, N., Yano, S. 2005.Characterization Of Salt-Tolerant Glutaminase From Stenotrophomonas maltophilia NYW-81 And Its Application In Japanese Soy Sauce Fermentation. The Journal Of Industrial Microbiology And Biotechnology, 32:383-390. Https://Doi.Org/10.1007/S10295-005-0257-7.

Wang, B., Relling, M.V., Storm, M.C., Woo, M.H., Ribeiro, R. 2003.Evaluation Of Immunologic Cross Reaction Of Anti-Asparaginase Antibodies In Acute Lymphoblastic Leukemia (ALL) And Lymphoma Patients. Leukemia, 17: 1583 1588. Https://Doi.Org/10.1038/Sj.Leu.2403011.

Wang, B., Erickson, J.W., Fuji, R., Ramachandran, S., Gao, P., Dinavahi,R., Wilson, K.F., Ambrosio, A.L., Dias, S.M., Dang, C.V., Cerione, R.A. 2010.Targeting Mitochondrial Glutaminase Activity Inhibits Oncogenic $\begin{array}{lll}\text { Transformation. } & \text { Cancer } & \text { Cell, }\end{array}$ Https://Doi.Org/10.1016/J.Ccr.2010.08.009.

Wetzler, M., Sanford, B.L., Kurtzberg, J., Deoliveira, D., Frankel, S.R., Powell B.L., Kolitz, J.E., Bloomfield, C.D., Larson, R.A. 2007. Effective Asparagine Depletion With Pegylated Asparaginase Results In Improved Outcomes In Adult Acute Lymphoblastic Leukemia: Cancer And Leukemia Group B Study 9511. Blood. 15;109 (10):4164-7. Https://Doi.Org/10.1182/Blood-2006-09-045351.

Woo, M.H., Hak, L.J., Storm, M.C. 2000. Hypersensitivity Or Development Of Antibodies To Asparaginase Does Not Impact Treatment Outcome Of Childhood Acute Lymphoblastic Leukemia. Journal Of Clinical Oncology, 18: 1525-1532. Https://Doi.Org/10.1200/JCO.2000.18.7.1525.

Yellin, T.O., Wriston, J.C. 1966. Antagonism Of Purified Asparaginase From Guinea Pig Serum Toward Lymphoma. Science 151: 998 - 999. PMID:5952048. Yamamoto, S., Hirooka, H. 1974. Production Of Glutaminase By Aspergillus sojae. Journal Of Fermentation Technology, 52: 564-556.

Yasser, R.A.F., Olama, Z.A. 2002. L-Asparaginase Production By Pseudomonas aeruginosa In Solid-State Culture: Evaluation And Optimization Of Culture Conditions Using Factorial Designs. Process Biochemistry,38:115-122. PMID: 27844015 .

Yokotsuka, T., Iwasa,, T., Fujii, S. 1987. Species Cryptococcus Nodaensis, A Pro- Cess For Producing Salt-Resistant Thermostable Glutaminase By Use Of The Same, And A Process For Producing Glutamic Acid-Rich Protein Hydrolysates. Nippon Shoyu Kenkyusho Zasshi, 13, 18-25. 
Young, M., Hee, S., Cheol, M. James, Y., Yoon, J., Scott, D., Allan, E., Victor, C. 2009. L-Asparaginase Encapsulated Intact Erythrocytes For Treatment Of Acute Lymphoblastic Leukemia (ALL).J Control Release. 139(3):182-189. Https://Doi.Org/10.1016/J.Jconrel.2009.06.027.

Yue, F., Song, L., Jiao, Y., Gao. H., Wang. M., Du, G., Chen, J.(2017). Enhanced Extracellular Production Of L-Asparaginase From Bacillus subtilis 168 By B. Subtilis WB600 Through A Combined Strategy. Applied Microbiolology And Biotechnoogyl, 101:1509-1520. Https://Doi.Org/10.1007/S00253-016-7816-X.

Zubavichus, Y., Fuchs, O., Weinhardt, L., Heske, C., Umbach, E. 2004. Soft XRay-Induced Decomposition Of Amino Acids: An XPS Mass Spectrometry And NEXAFS Study.Radiation Research, 161, 346 -358. PMID: 15108. 